كار آيى بهرهمندى از آب باران گندم (Triticum aestivum L.) تحت تأثير جهت خاكورزى در كثتزارهاى ديم شيبدار

على رضا واعظى"، احسان زرين آبادى و ياسين صالحى'

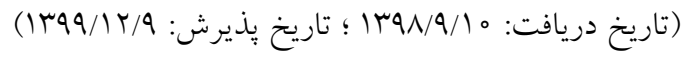

جكيده

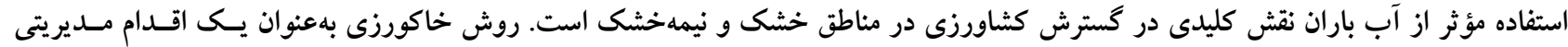

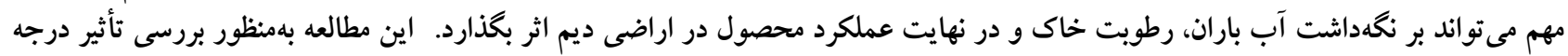

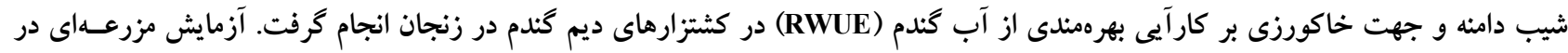

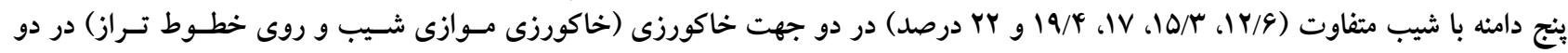

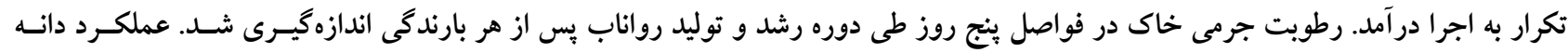

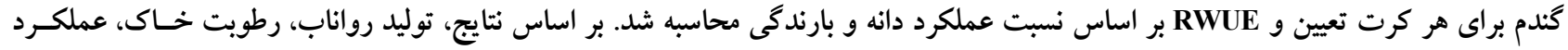

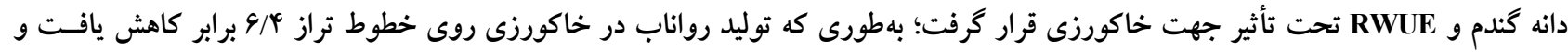

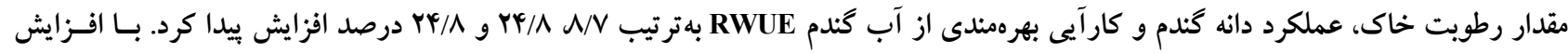

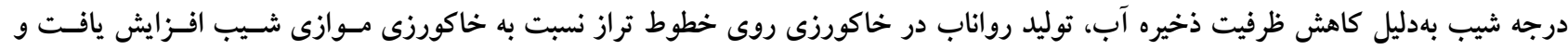

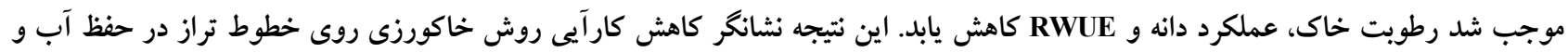
RWUE

وازههاى كليدى: بارندگى، خاكورزى حفاظتى، رواناب، عملكرد گندم، محتواى رطوبتى خاك.

1 ا. كروه خاكشناسى، دانشكده كثاوزىى، دانشخاه زنجان

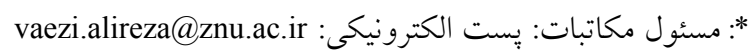


خاكورزى حفاظتى حـداقل بـهـهـم خــوردگى خــاكى و حسداكثر

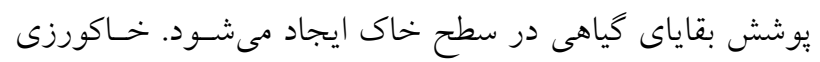

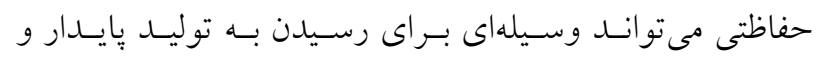

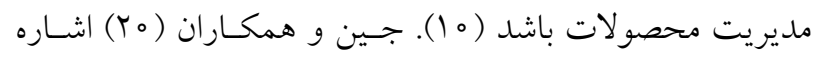

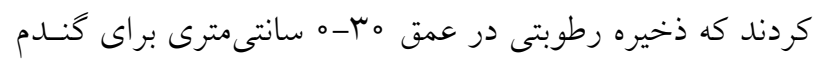

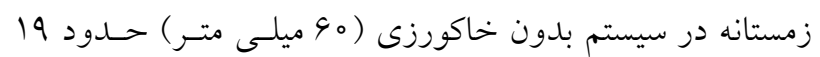

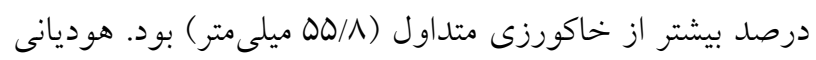

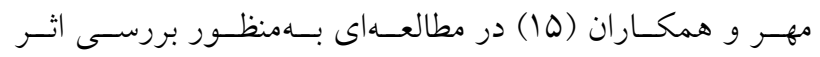
سيستمهاى خاكورزى بـر محتـواى عناصـر و عملكـــد دو گيـاه

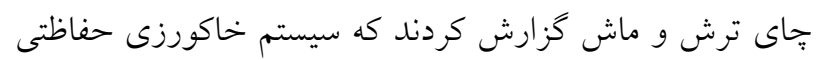

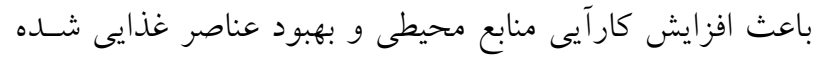

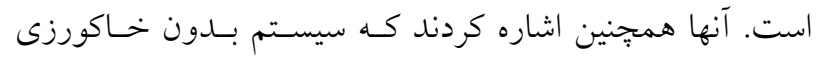
محتواى رطوبتى بيشتر و دماى خاك كمترى نسـبت بـه سيسـتم

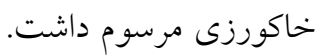

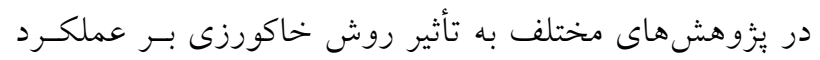
محصولات كشاورزى يرداخته شده است. احمدى و همكـاران

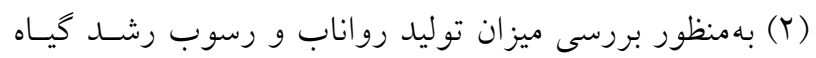

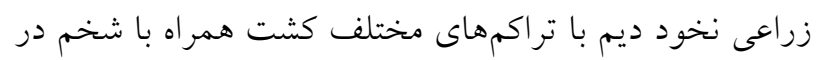

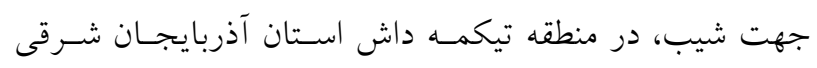

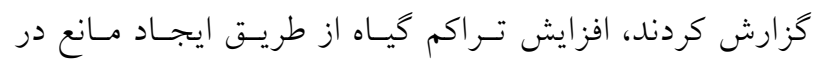

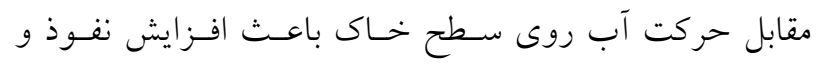
كاهش رواناب شد. شريفى و همكاران (بآ) در مطالعهاى اثـر روش هاى شخم بر عملكرد و اجزاى عملكرد كُندم در بيرجند

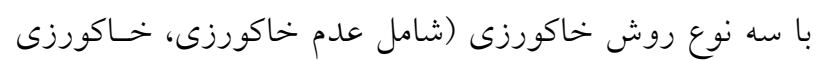

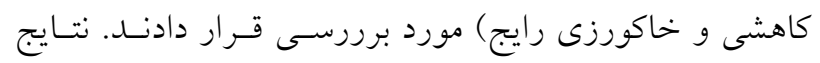

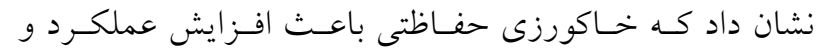

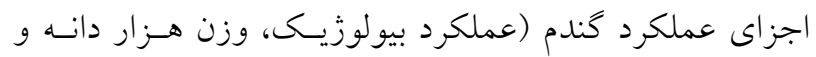

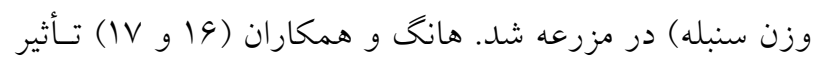
سيستمهاى مختلف خاكورزى بـر خصوصسيات خـاك و گيـاه

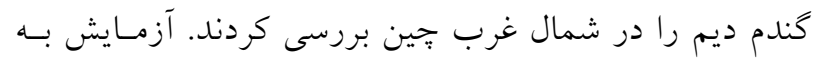

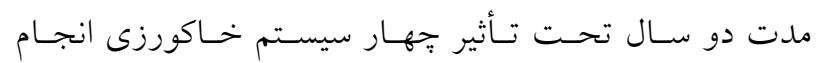

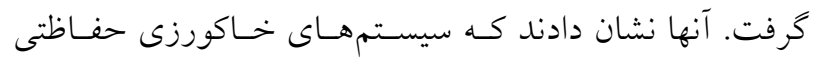

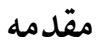

كندم (Triticum aestivum L.) از كَاهان كَدار تكلهِاى يكسـاله

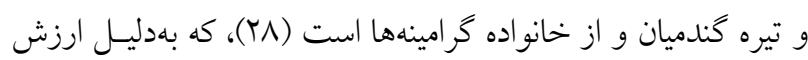

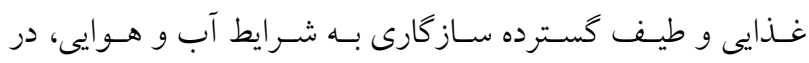

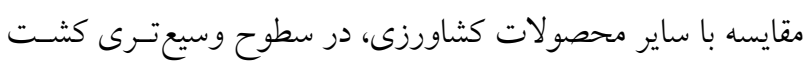

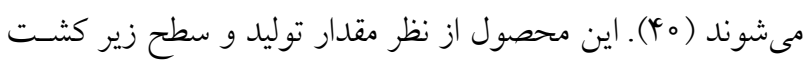
مهمترين محصول كشاورزى در ايران نيز است كه افزايش توليد آن

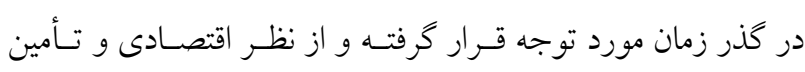

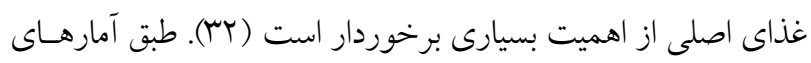

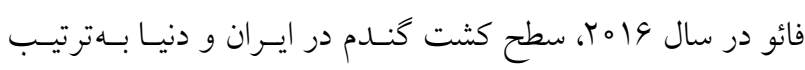

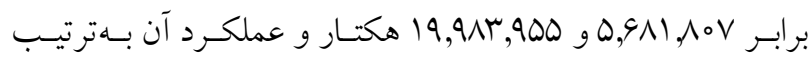

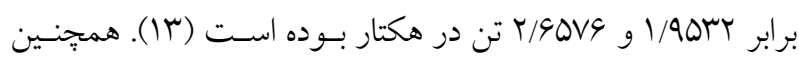

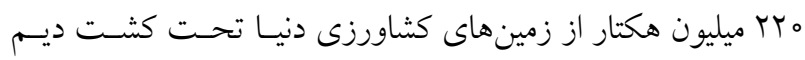
است و در ايران حدود ب ميليون هكتار تحت كشت ديسم قـرار دار دارد

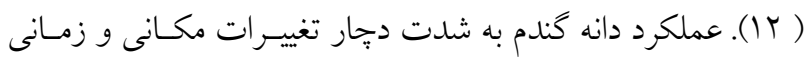

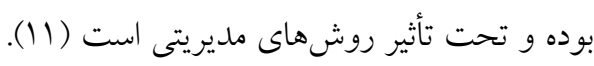

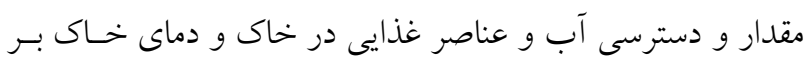

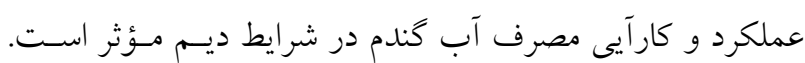

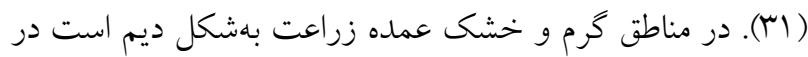

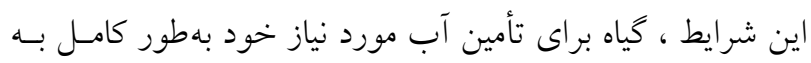

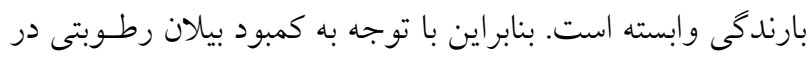

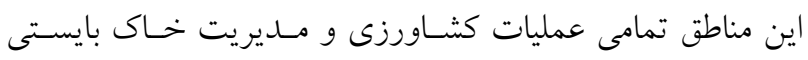

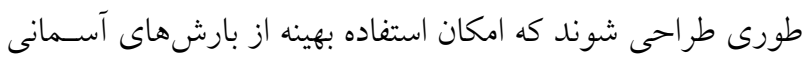

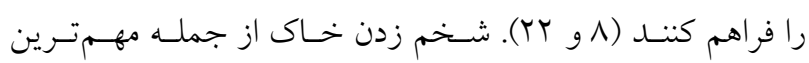

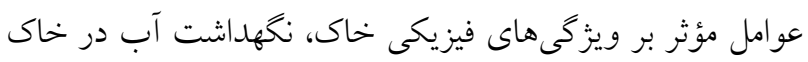

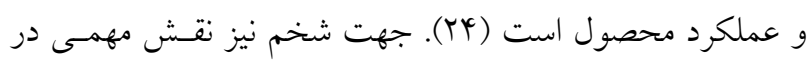

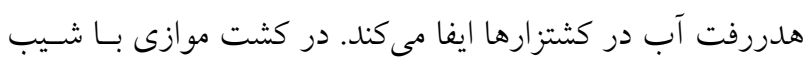

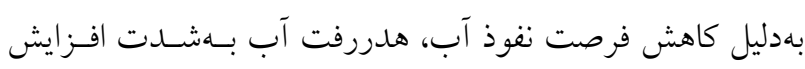

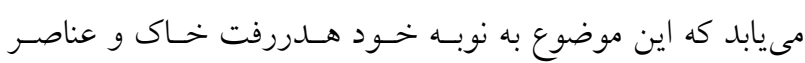

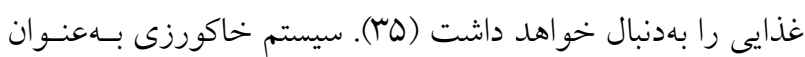

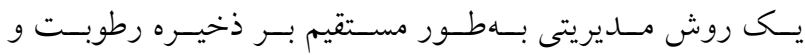

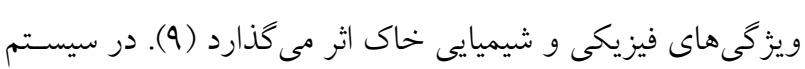




\section{مواد و روشها طرح آزمايشى}

آزمايش بهصورت فاكتوريل در قالب طرح بلوى كامل تصـادفى دانى

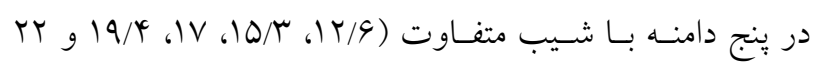

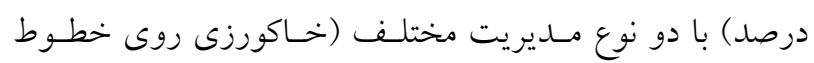

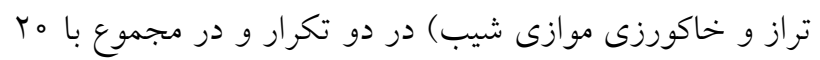

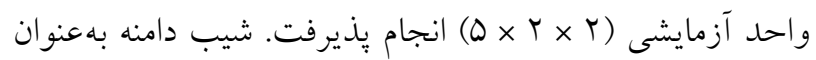

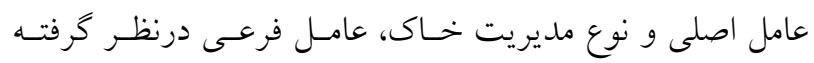

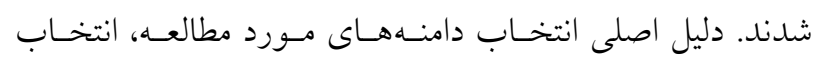

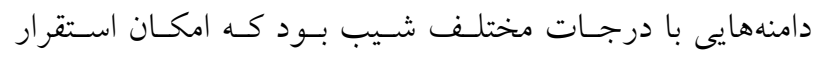

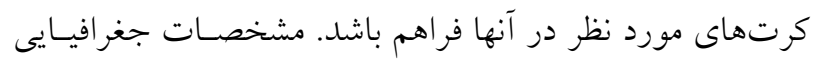
دامنهها، درصد شيب و بافت خاك در (جلدول () آمده است.

\section{ويزّى هاى منطقه مورد مطالعه}

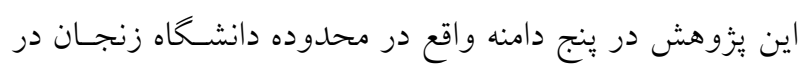

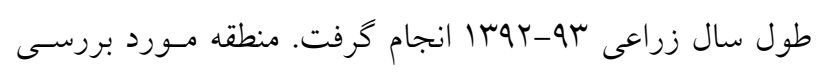

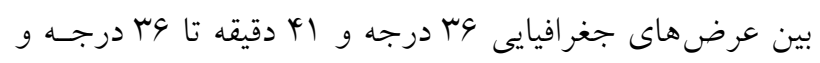

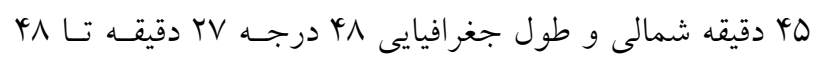
درجه و 9ه دقيقه شرقى قرار گرفته و ميانخين ارتفاع 1901 متـر

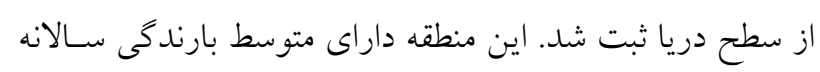

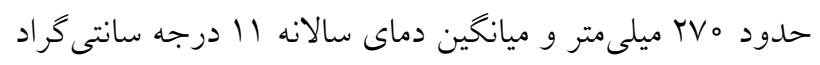

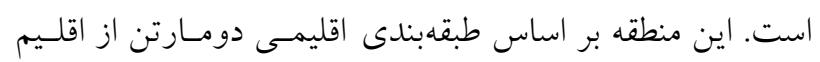

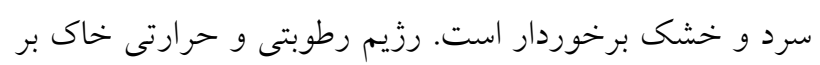

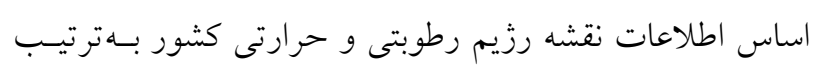

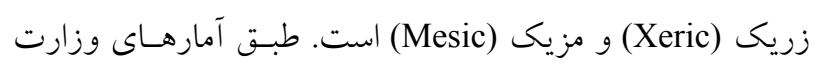

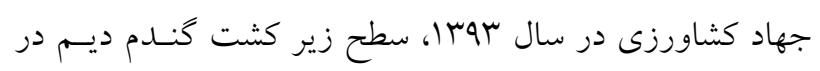

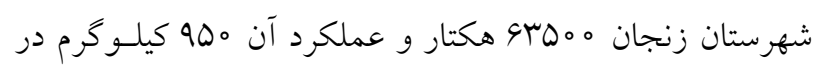

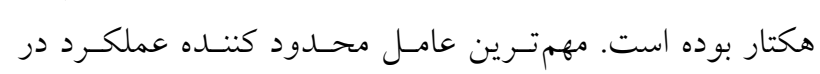

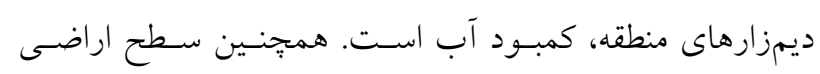

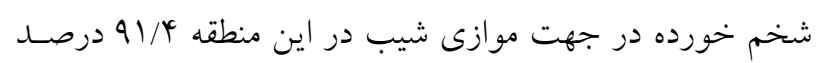

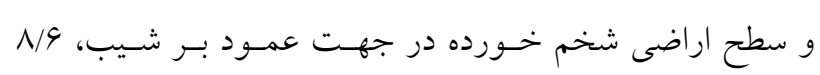
مرصد است.
نسبت به خاكورزى مرسوم باعث بهبود عملكرد دانه، كـارآيى

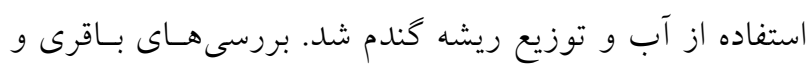

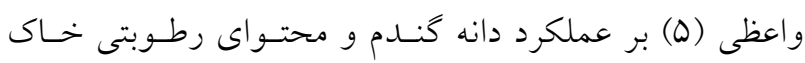

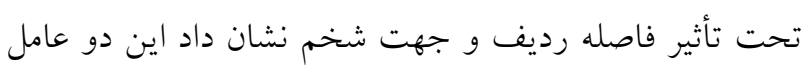

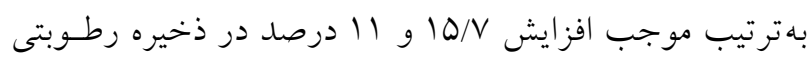

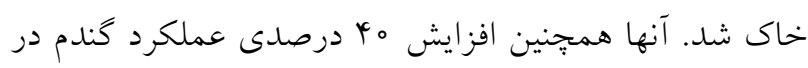

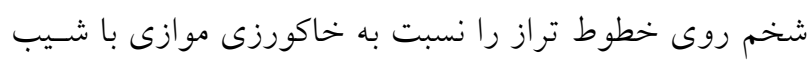
كزارش كردند. ياريهار و همكاران (ro) در تحقيقى در شـمال

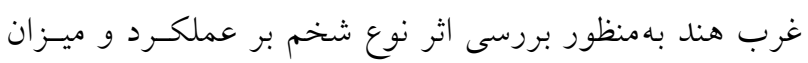

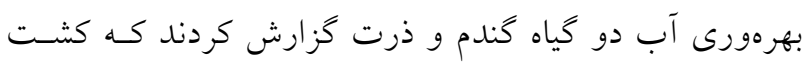

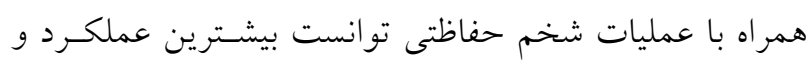

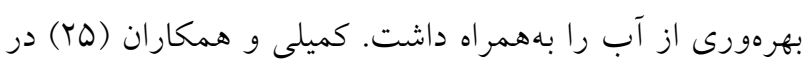

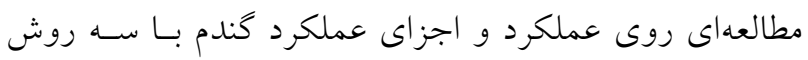

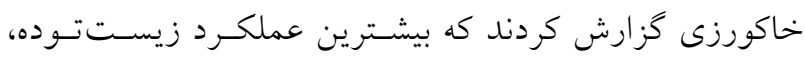

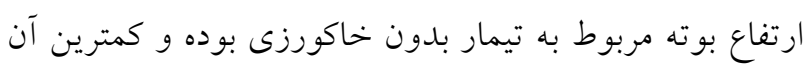
از سيستم كمخاكورزى بهدست آمد.

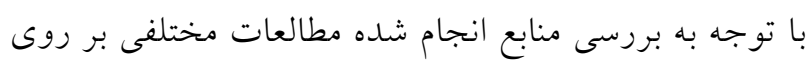

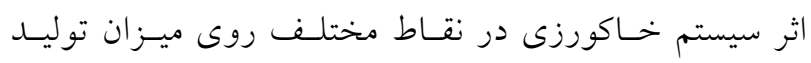

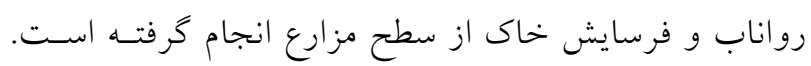

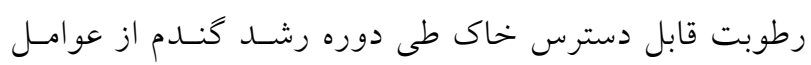

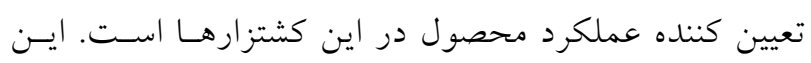

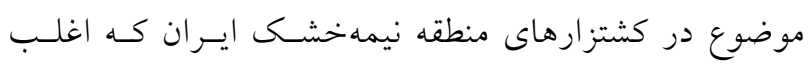

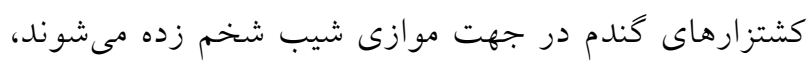

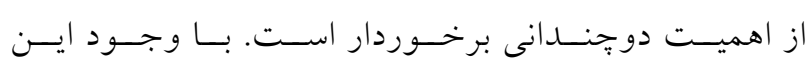

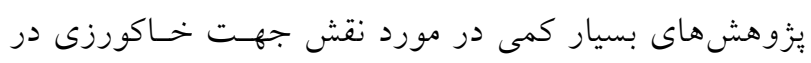

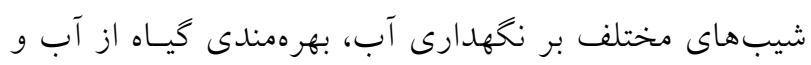

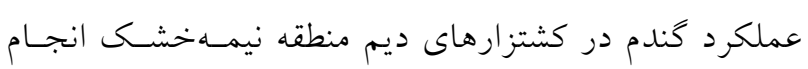

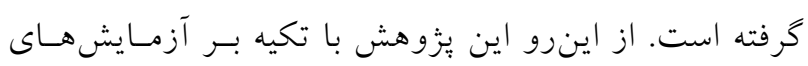

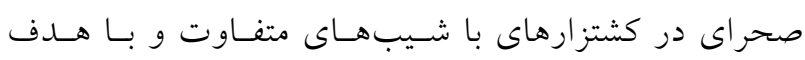

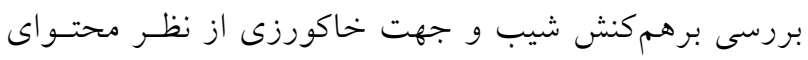

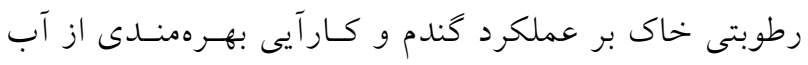

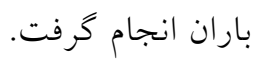


جدول ا. مشخصات جغرافيايى دامنهها، درصد شيب و بافت خاى

\begin{tabular}{|c|c|c|c|c|}
\hline بافت خاك & عرض جغر افيايى (درجه) & طول جغرافيايى (درجه) & ارتفاع از سطح دريا (متر) & شيب دامنه (.\%) \\
\hline لومرسىشنى & rq/9 & $\Psi \wedge / \mu_{\Lambda} \mu_{\circ} \circ Q$ & 1011 & $1 T / 9$ \\
\hline لومشنى & r $4 / 9 \wedge r_{\circ \circ G}$ & $\uparrow \wedge / \mu_{\Lambda} \mu_{\circ \circ \varphi}$ & 1090 & $10 / \mu$ \\
\hline لومشنى & $r 4 / 99901 r$ & 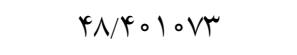 & 1901 & IV \\
\hline ل ل ومرسى شنى & r9/999014 & $\Psi N / Y \circ \mid \circ \circ V$ & $19 \circ 1$ & $19 / 4$ \\
\hline لومشنى & r $/ 9 \wedge \mu \circ \circ V$ & $ץ \wedge / \Gamma \wedge \Gamma_{0}$ & 1091 & rr \\
\hline
\end{tabular}

كرت) بود. در مجموع مr كرت در قالب طرح بلـوك كامـل تصادفى احداث شد. انـدازهگيـرى رطوبـت اوليسه خـاك در كرتها همزمان با كشت كندم ديم در اواخر مهر بوسا آغاز

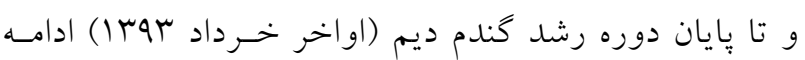
بيدا كرد. شكل ا نماى استقرار كرتها روى دامنسه را نشـان مىدهد. براى ايجاد كرتهاى شخم خورده در جهت موازى شيب و روى خطـوط تــراز (در جهـت عمــود بـر شـيب) از

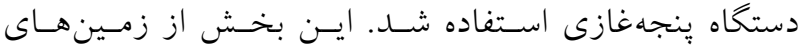
آزمايش بهوسيله دستخاه ينجهاغازى بهصورت سطحى (صـفر

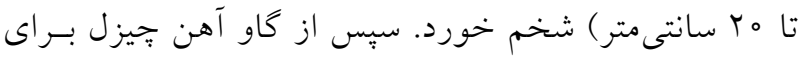
آمادهسازى بستر بذر استفاده شد. كشت كندم ديم در اواخـر مهر ماه r ب ا بهوسيله دستخاه خطى كار در دو جهـت شـخم (عمود بر شيب و موازى شيب) انجام كرفتـ. عمـق كاشـت كندم ه سانتىمتر و فاصله رديف هاى كشـت م r سـانتىمتـر

تعيين عملكرد گندم و كار آيى بهرهمندى از آب باران براى تعيين عملكرد دانه و مـاده خشـك در هـر كـرت تحـت كشت، بوته هاى كندم با استفاده از نمونه گير مربعى به مساحت يك مترمربع برداشته شد (TV) و تعداد و جرم خشك بذور در هر بوته تعيين شد. درنهايست بـا اسـتفاده از روابـط ( (1) و (Y) عملكرد دانه گندم براى هر كرت محاسبه شد: $\mathrm{Y}_{\mathrm{G}}=\frac{\mathrm{M}_{\mathrm{G}} \mathrm{N}_{\mathrm{S}} \times 10000}{\mathrm{~A}}$
تعيين ويزگى هاى خاى كثتزارها براى اندازهخيرى ويزخى هــاى خـاى دامنسهــا، يـيش از شـروع كشت، نمونههايى از عمق صفر تا هب سانتىمترى در سـه نقطـه

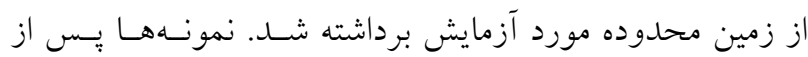
كذراندن از الكى دو ميلىمترى براى انجام آزمايشهاى فيزيكى

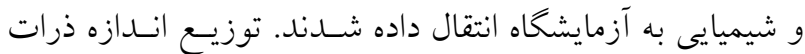
به روش هيدرومترى (1 (1)، pH خاك به وسيله pH سنج در گل اشباع (Y\&) و درجه شورى بهوسيله ECسنج بر مبنـاى رسـاناى

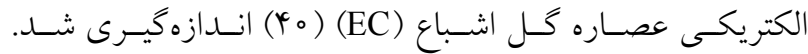
همجينين كربنات كلسيم معادل بهروش تيتراسيون (Iال)، ظرفيت تبادل كاتيونى بهروش باور (Yq) و محتواى كربن آلى بـهروش والكى بلاك (q) تعيين شد. در نمونههاى خاك دستنخـورده ميانخين قطر خاكدانهها از طريق جداسازى خاكدانهها بـهوسـيله سرى الكىها و محاسبه ميانگين وزنى قطر خاكدانهها و پيايدارى خاكدانهها در نمونههاى خاكدانه با قطر و تا م ميلىمتر بـهروش الكى تر با جداسازى خاكدانههاى يايدار در آب (بآ) بـه مـدت

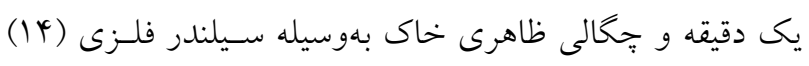

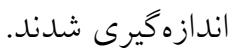

\section{اجراى آزمايش}

در طول هر دامنه جهار كرت به ابعـاد بامتـر در ه متـر در مهـر r 1 ا احداث شد. كرتها شامل كرتهاى تحت كشـت گنـدم ديم در جهت موازى شيب (r كرت) و كرتهاى تحست كشـت كندم ديم در جهت عمود بـر شـيب يـا روى خطـوط تـراز 


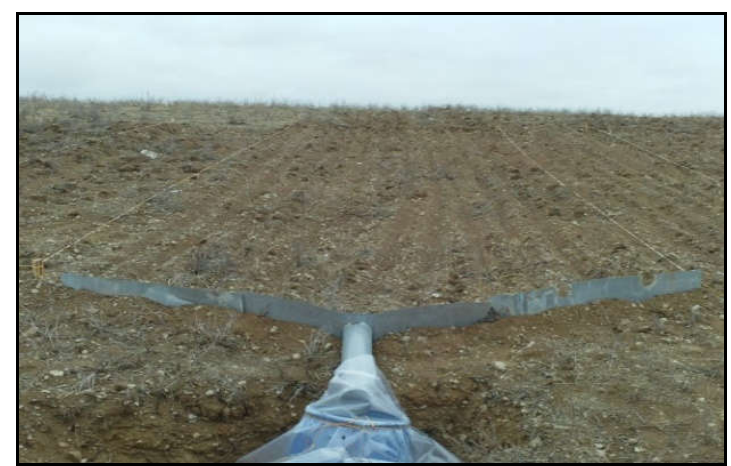

شكل ا. نمايى از استقرار كرتها روى دامنه شيبدار

هر بارندگى منجر به رواناب، حجم كـل روانـاب كـرت در هـر

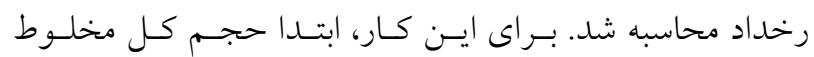

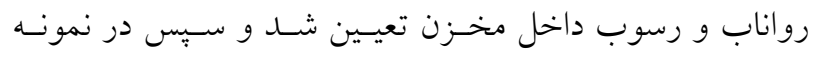

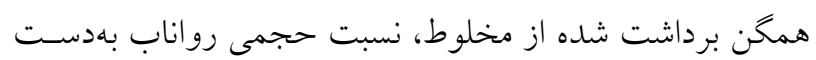

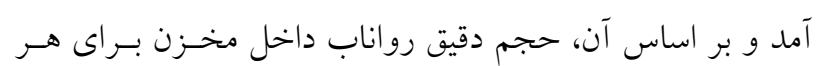
رخداد بارندگى محاسبه شد (Nی).

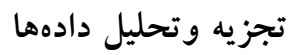

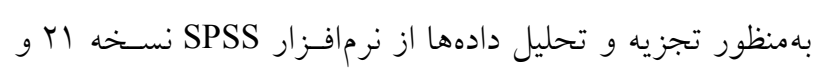

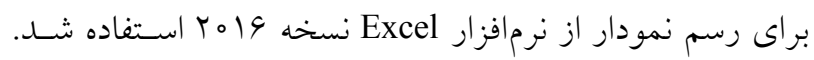

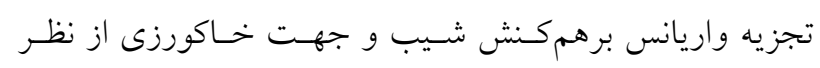

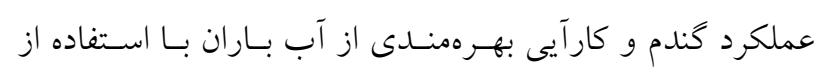

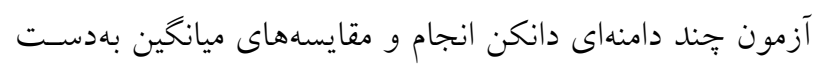
آمد. شكل r نمودار كلى روش كار را نشان مىدهد.

\section{نتايج و بحث}

ويز گیىهاى خاى كشتزارها

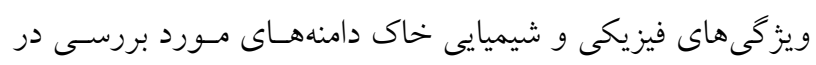

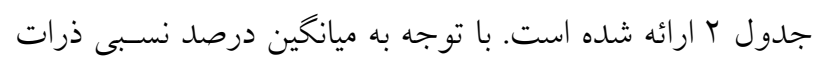

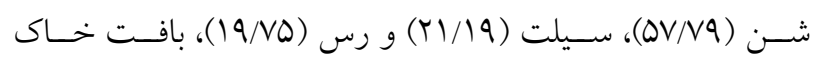
دامنهاى مورد بررسى در دو كلاس لومشنى و لومرسشنى قـرار

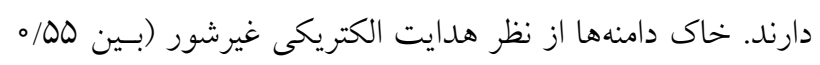

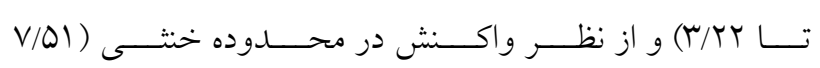

كه در آنها: YG عملكرد دانه در هكتار (Kg/ha)، MG جرم دانه-

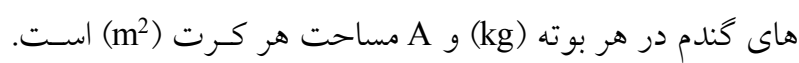

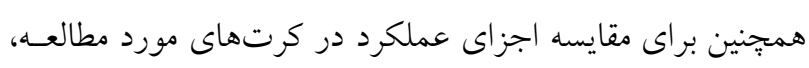

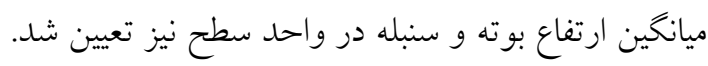

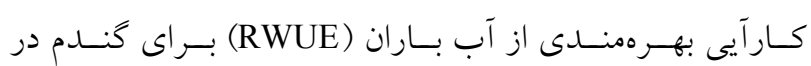

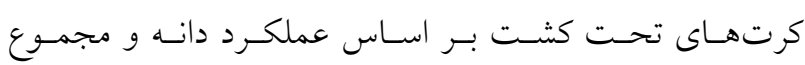

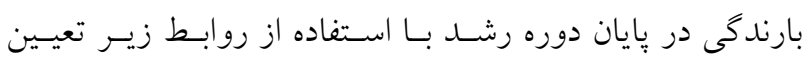

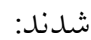
$\operatorname{RWUE}_{\mathrm{G}}=\frac{\mathrm{Y}_{\mathrm{G}}}{\mathrm{p}}$ كه در آنها: RWUEG كارآيى بهرهمندى از آب باران بـراى دانسه

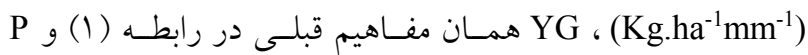
ميزان بارندكى طى دوره رشد (ميلىمتر) است. تعيين رطوبت خاك و رواناب طى دوره رشد

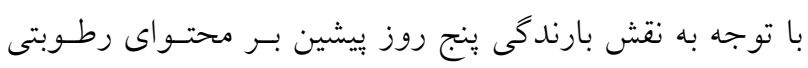

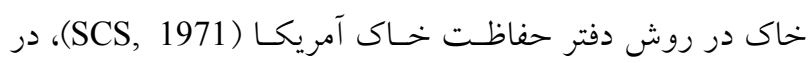

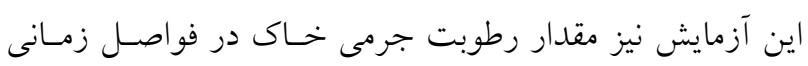

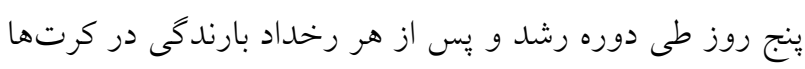

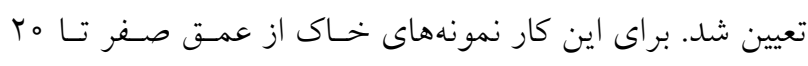

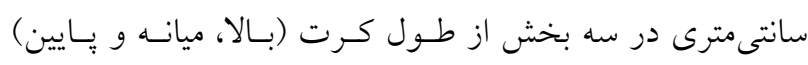

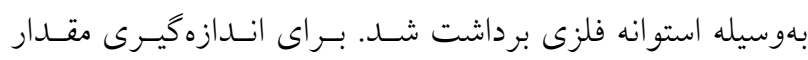

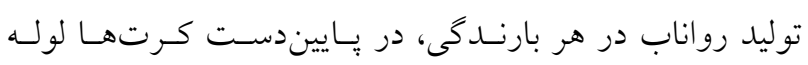

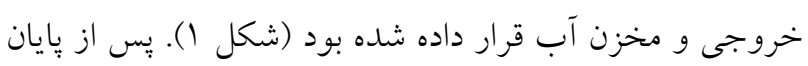




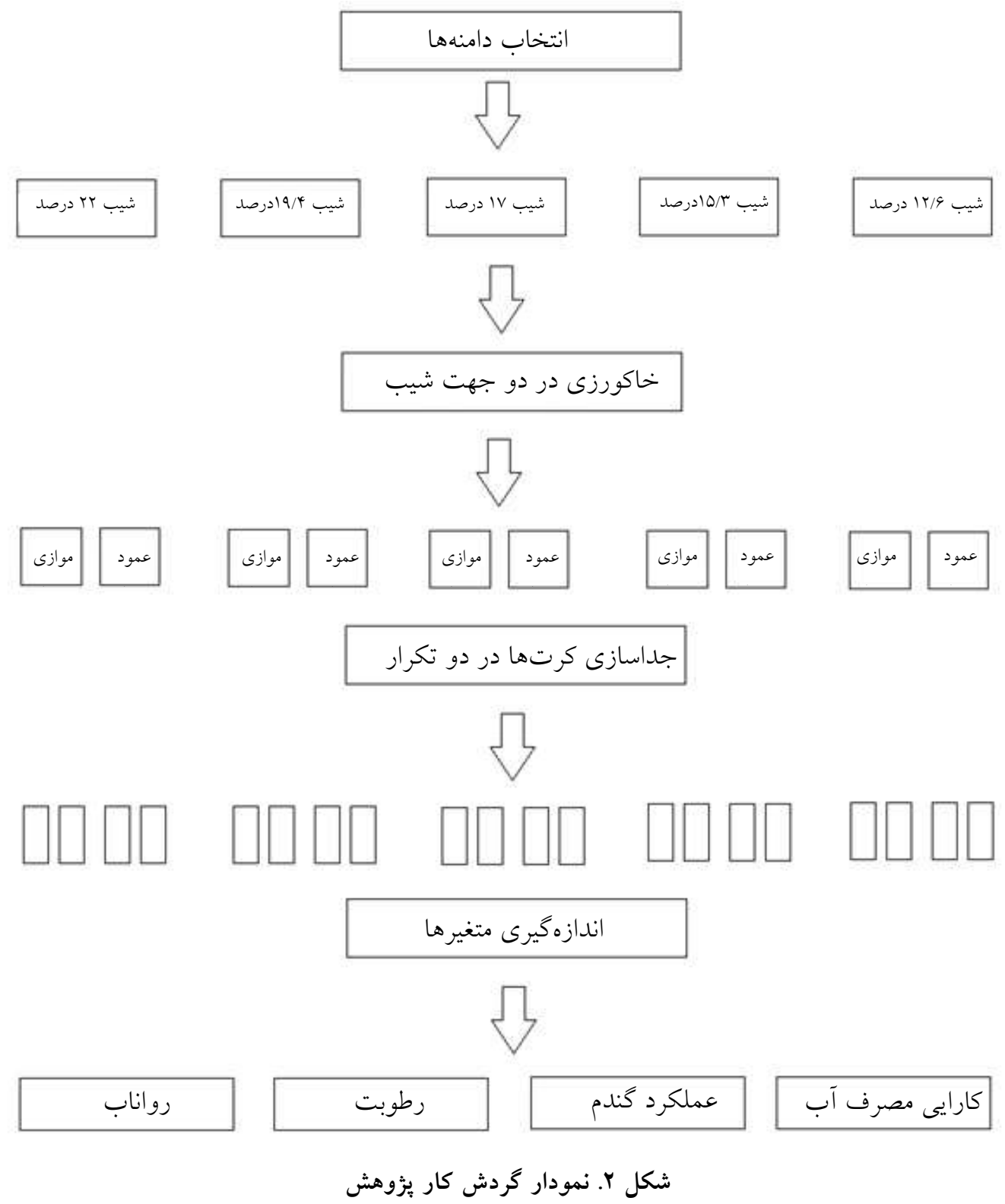

تشكيل و وِايدارى خاكدانه ها شده (V) و احتمال فروياشسى تا V/N/ بود. خاكها بهعلت داشتن كربنـات كلسـيم بـهنسبت

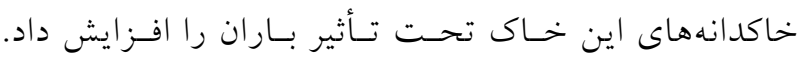

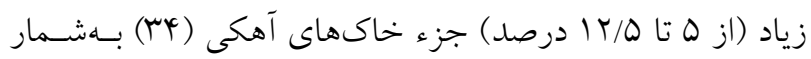

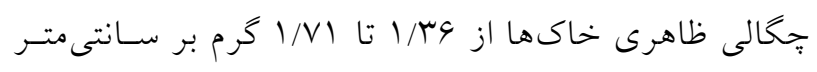
مىروند. خاكها به لحاظ داشتن مقادير كمتر مادة آلى (حسداكثر مكعب متغير بود كه اغلب بهدليل وجود ذرات درشت دانه

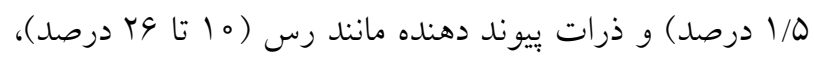

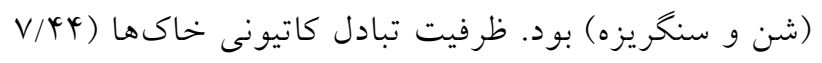

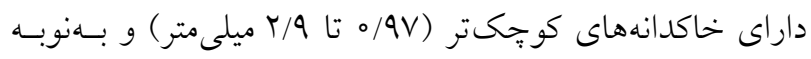

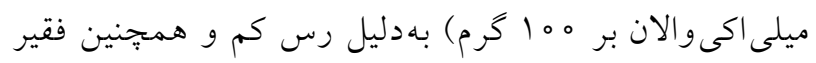

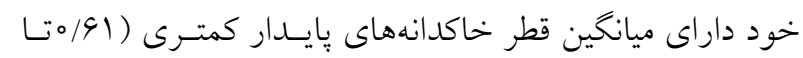

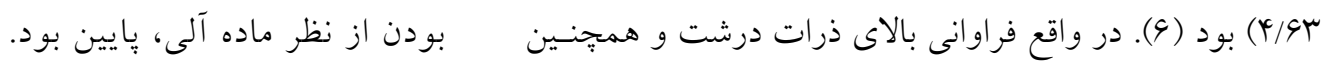
ذرات سست فاقد جسـبندگى (سـيلت و شـن) در خـاك مـانع 


\begin{tabular}{|c|c|c|c|c|}
\hline ضريب تغييرات (.) & بيشترين & كمترين & ميانكين & ويزگكى هاى خاك \\
\hline & & & & ويزگ هى هاى فيزيكى \\
\hline 14 & $\mathrm{Vq} / \mathrm{VI}$ & $\mu r / 9 \mu$ & $\Delta V / V q$ & 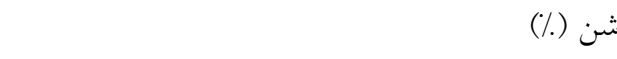 \\
\hline IV & rA & 10 & $r 1 / 19$ & سيلت (.) \\
\hline rq & rq & 10 & $19 / 9 \mathrm{~V}$ & رس (.) - ل \\
\hline$\Delta \wedge$ & $\varphi 1 / 4 \circ$ & G/NG & $19 / \pi r$ & سنخر يزه (\%) \\
\hline$\wedge$ & $|N|$ & $1 / \mu_{4}$ & $1 / 49$ & בجكالى ظاهرى (كرم بر سانتىمتر مكعب) \\
\hline ro & $r / 90$ & $\circ / 9 V$ & $1 / 94$ & ميانكين قطر خاكدانه در روش الك خشك (ميلىمتر) \\
\hline Q9 & $r / 9 r$ &.$/ 91$ & $r / 49$ & ميانگين وزنى قطر خاكدانه بِيدار در آب (ميلىمتر) \\
\hline & & & & ويز خى هاى شيميايى \\
\hline 1 & V/Ar & $V / D)$ & $V / 9 \Lambda$ & 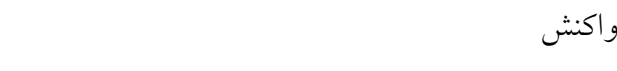 \\
\hline Gr & $r / r r$ & $\circ / \Delta \Delta$ & $1 / \pi 1$ & 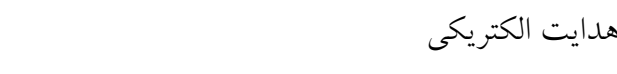 \\
\hline ro & $10 / \pi r$ & $\Delta / 4 \varphi$ & $V / 4$ & ظرفيت تبادل كاتيونى \\
\hline$r$ & $1 / 01$ & $\circ / 94$ & $1 / 19$ & 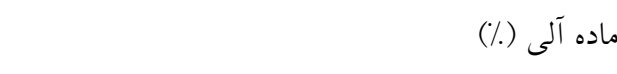 \\
\hline rq & $1 Y / Q$ & 0 & $10 / 0 \wedge$ & كربنات كلسيم معادل (.) \\
\hline
\end{tabular}

كار آيى بهرهمندى از آب باران نشان داد كـه عملكـــد دانـه

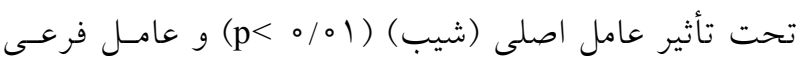

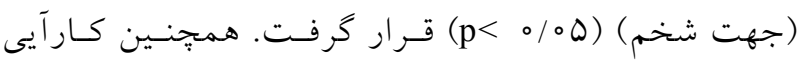

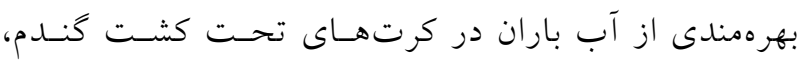
تحت تأثير عامل اصلى (شيب) ( 1 (

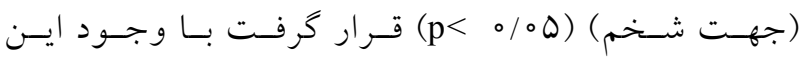
برهم كنش اين دو عامل از نظر تأثير بر عملكرد دانه كَندم و كار آيى بهرهمندى از آب بـاران معنسى دار نبـود. ايسن نتسايج

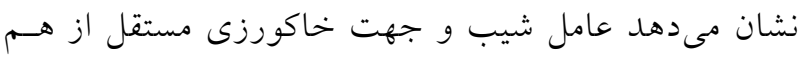
بر متغيرهاى مورد بررسى اثر مى گذارند. بهعبارت ديخر در

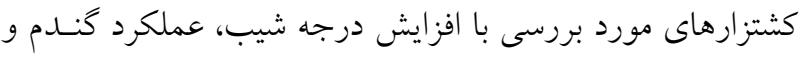

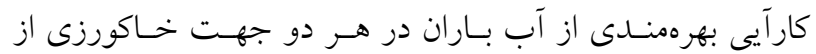

ويزگگىهاى بارانهاى طبيعى طى دوره مطالعاتى

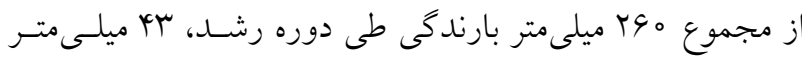

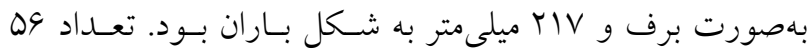

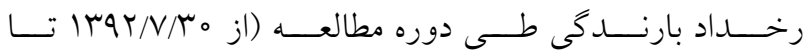

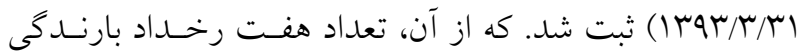

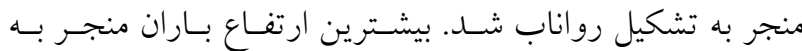

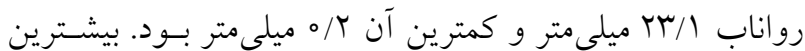

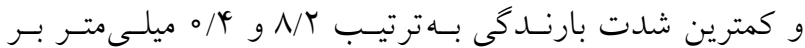

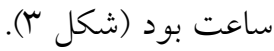

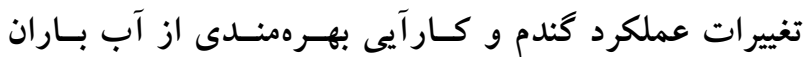
تحت تأثير شيب دامنه و جهت خاكورزى

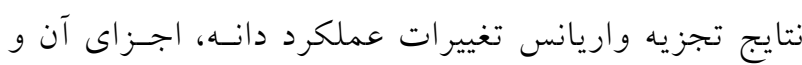




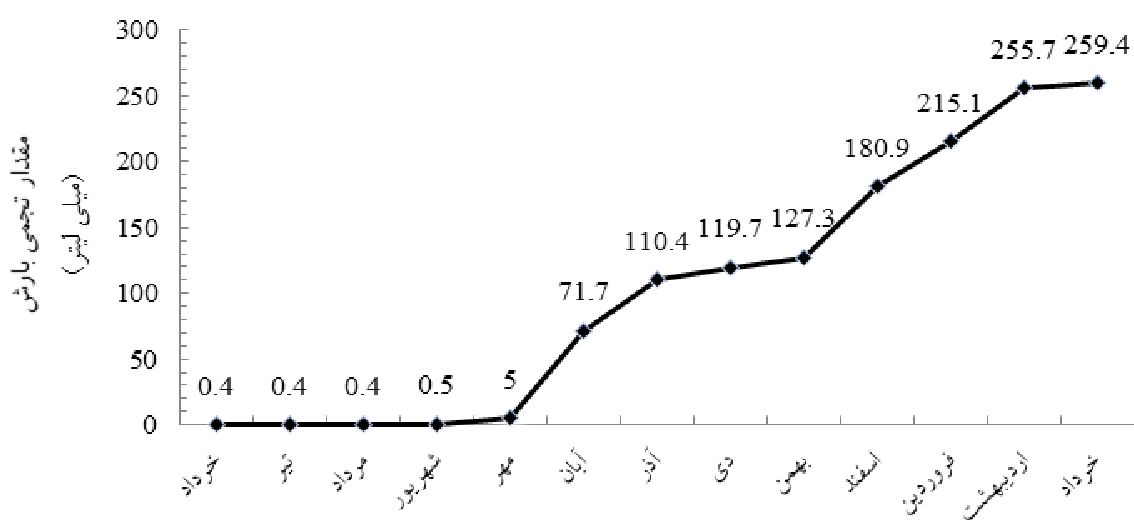

ماء هاى سال

شكل r. مقدار بارندگى تجمعى ماهانه از خرداد بqسا تا پايان خرداد بهץ|

جدوله. تجزيه واريانس عملكرد دانه كندم و كار آيى بهرهمندى از آب باران از نظر درجه شيب و جهت خاكورزى

\begin{tabular}{|c|c|c|c|c|}
\hline رو اناب & كارآيى بهرهمندى مربعات از آب & عملكرد & درجه آزادى & متغير \\
\hline $\mid Y / \Lambda G Y^{*}$ & $\circ \mu \circ \varphi^{* * *}$ & $\circ / \mu \circ \Lambda^{* * * *}$ & r & شيب \\
\hline $0 / 01 Y$ & 。 & 。 & Q & خطاى عامل اصلى \\
\hline$\varphi q / \backslash \wedge \mu^{* * * *}$ & ०००१* & *०/०४q & 1 & جهت خاكورزى \\
\hline 。 & $\circ / \circ \circ \Delta$ & $\circ / 0 \circ 0$ & 0 & خطاى عامل فرعى \\
\hline 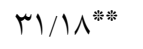 & $\circ / \circ \circ)^{\mathrm{ns}}$ & ns $0 / 001$ & r & شيب × جهت \\
\hline
\end{tabular}

(4/1 درصد جرمى) بود. بـرخلاف محتـواى رطـوبتى خـاك،

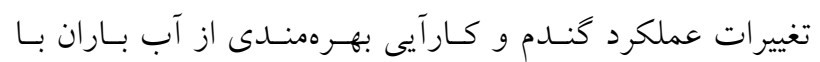

افزايش شيب دامنه از الخوى مشخصى بيروى نكرد.

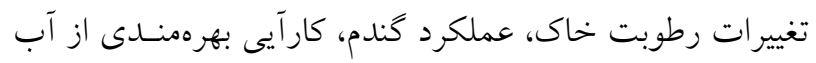
باران و رواناب در جهتهـاى مختلـف خـاكورزى در شـكل ه ه نشان داده شده است. بهطور كلسى در خـاكورزى روى خطـوط تراز، محتواى رطوبتى خاك بهطور ميـانگين N/V درصسـ بيشـتر ازخاكورزى موازى شيب بود. تغييرات رطوبت جرمى خـاك در دو جهت خاكورزى در دامنهاى مورد بررسسى در طـول فصـل رشد در شكل و نشان داده شده است. رطوبـت خـاك از شـيب IV/9 درصد تا شيب IV درصـد كـاهش يبـدا كـرد و در شـيب 19/4 درصد افزايش يافت. اين افزايش رطوبت بهدليـل درصسد
روند مشابهى بيروى مى كند (جدول $).$

تغييرات رطوبت خاك، عملكرد گندم، كار آيى بهرهمنـدى از آب باران و رواناب تحت تأثير جهت خاكورزى در شكل ب تغييرات رطوبت خاك، عملكرد گنـدم، كـارآيى بهرهمنــى از آب بـاران و روانـاب را تحست تـأثير جهـت خـاكورزى (خــاكورزى مــوازى شـيب و خهـاكورزى روى ته خطوط تراز) در درجـات متفـاوت شـيب نشـان داده شـده است. مقايسه بين دو جهت خاكورزى نشان داد كه بيشترين تفاوت در محتواى رطـوبتى خـاك در شـيب / I ا درصـد (9/11 درصد جرمى) و كمترين تفاوت در شيب r T درصد 

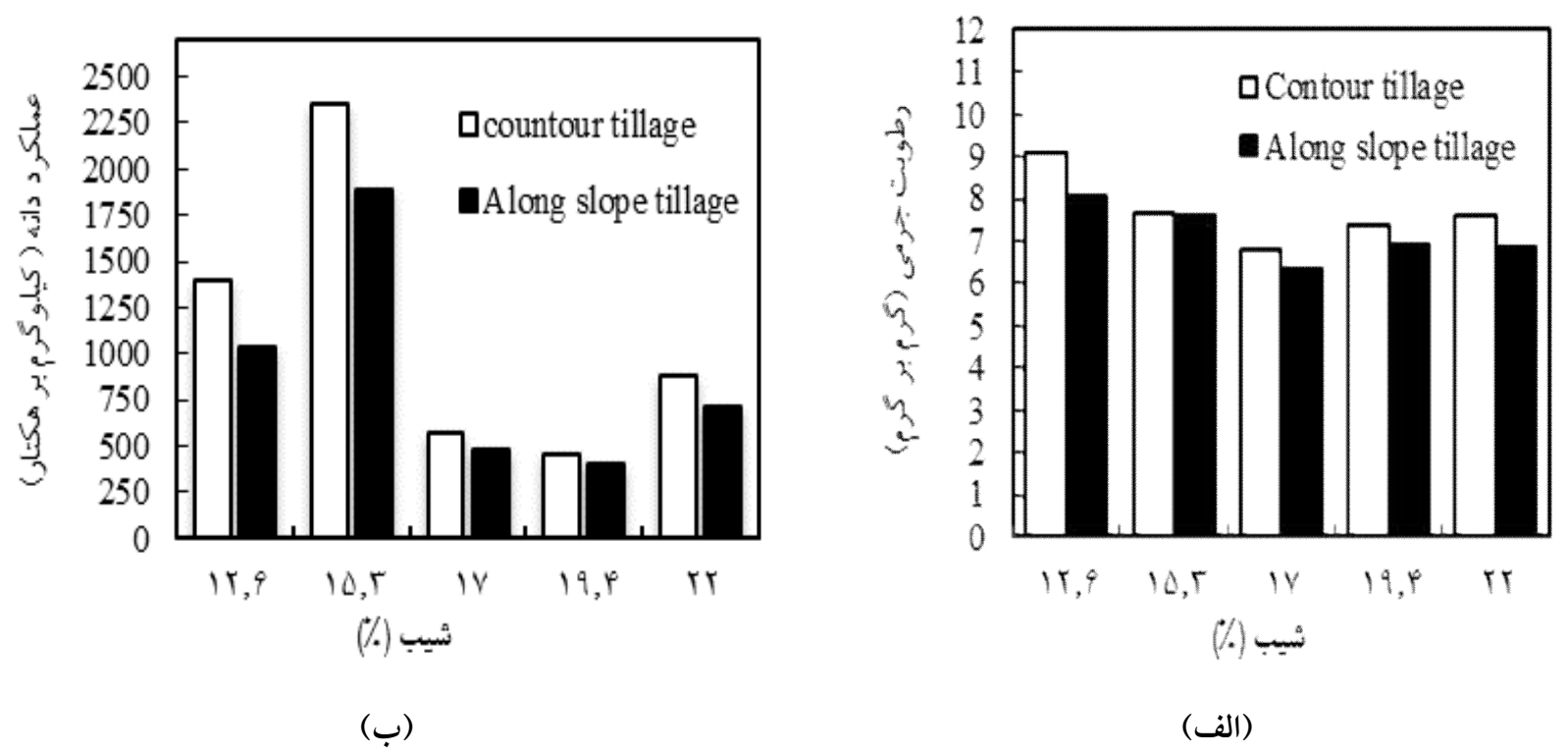

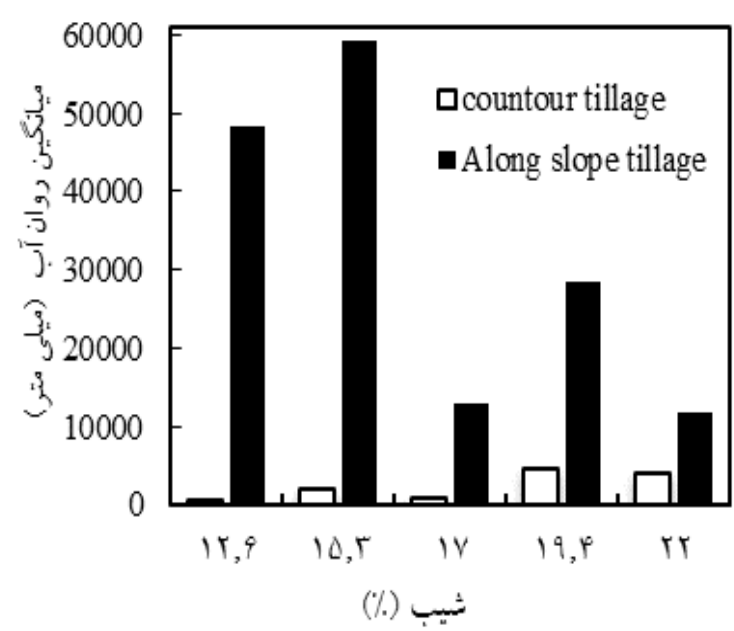

(د)

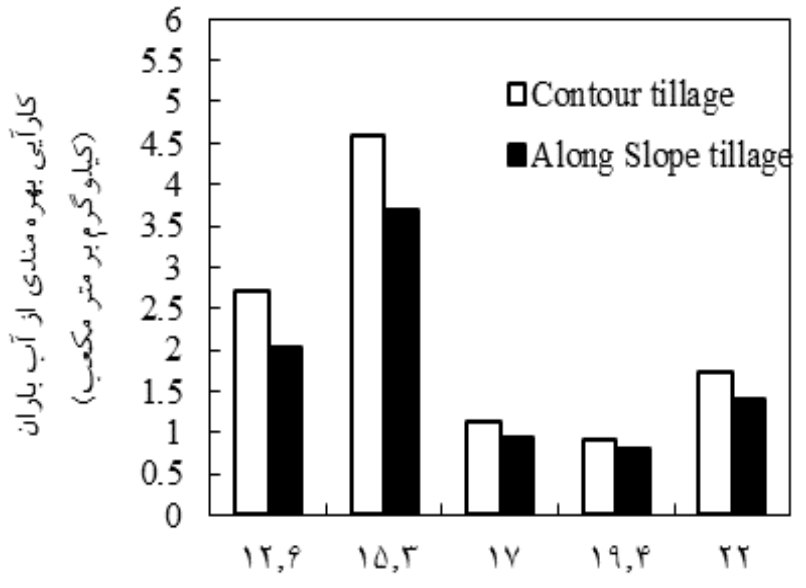

شيب (م)

(ج)

شكل f. تغييرات: الف) رطوبت خاك، ب) عملكرد گندم ديم، ج) كارآيى بهرهمندى از آب باران و د) ميانگين رواناب تحت تأثير جهت خاكورزى در درجات متفاوت شيب

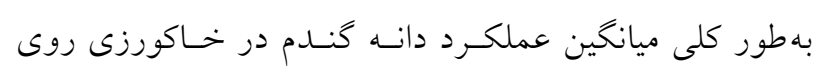

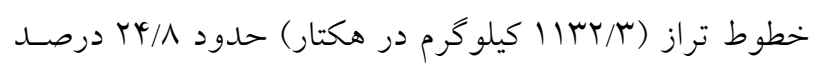

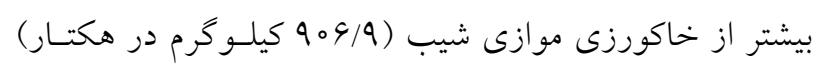

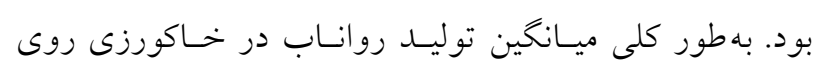
خطـوط تــراز ( خاكورزى موازى شيب (19004 ميلى ليتر) بود. اين نتايج تأييد

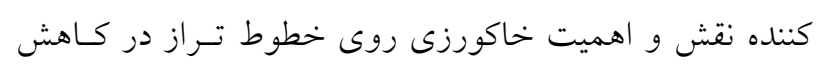

بالاى سيلت و رس نسبت به ساير شيبهـا بـود. همجنـــن از

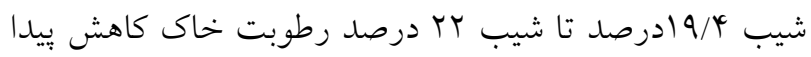
كرد. تغيير جهت شخم (شـخم روى خطـوط تـراز بـه شـخم

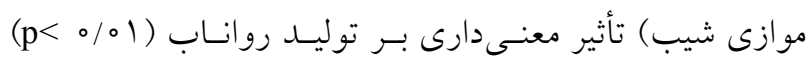

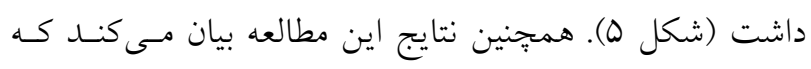

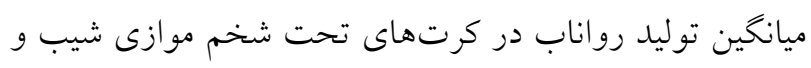

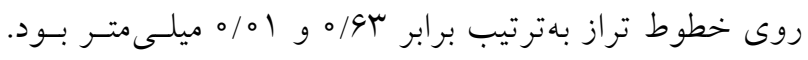




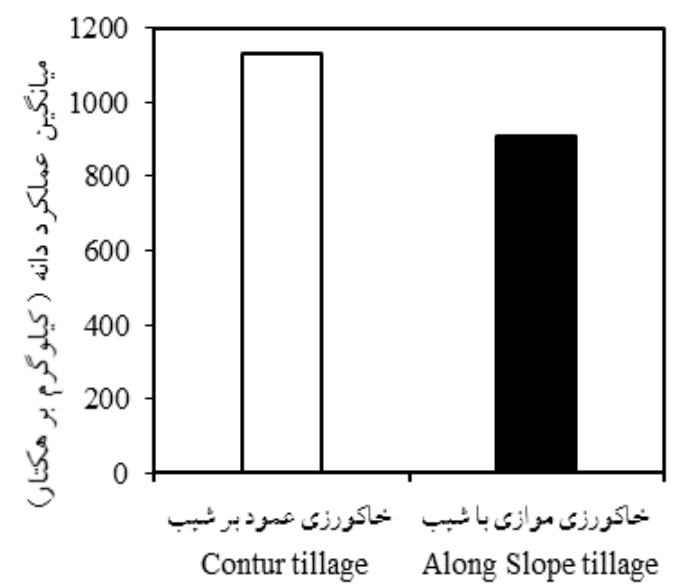

جهت خحاكوزى

(ب)

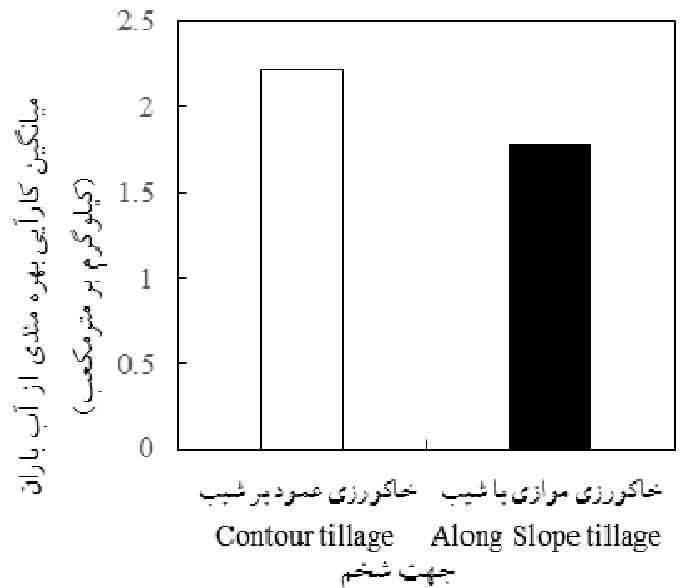

(د)

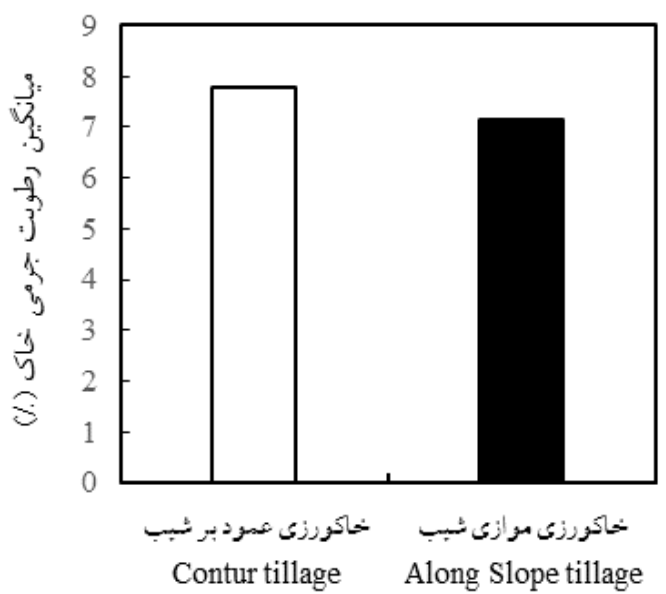

جهت خحاكورزى

(الف)

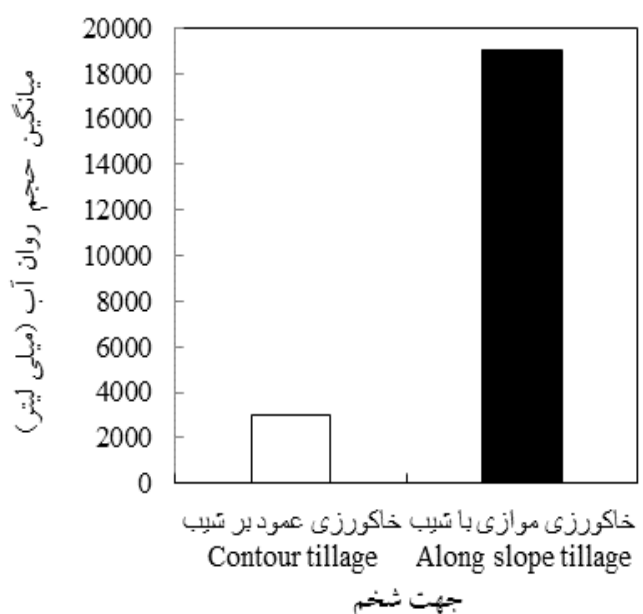

(ج)

شكل ه. تغييرات: الف) رطوبت جرمى خاك، ب) عملكرد دانه گندم، ج) كارآيى بهرهندى از آب باران و د) ميانگين حجم رواناب در دو جهت خاكورزى

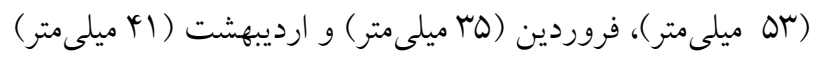

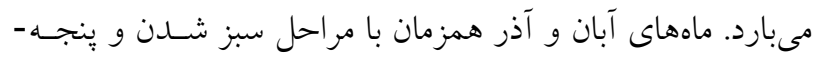
زنى است. در اين مراحل رشد رويشى گياه اندى است. با شـروع فصل بهار و آغاز مراحل ساقه روى، گلددهى و در ادامه ير شدن دانهها بيشترين رشد كياه اتفاق مىافتد. ذخيـره آب بـاران در ايسن مراحل از رشد نقش حياتى در دستيابى به عملكــرد بيشـتر كنـدم دارد، با وجود اين تنها از بr درصـد از بارنـدگىهـا در مـاههـاى

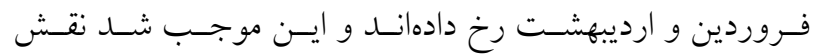
خاكورزى روى خطوط تراز در افزايش محتـواى رطـوبتى خـاك
توليد روانـاب و افـزايش محتـواى رطـوبتى خــاك اسـت كـهـ درنهايت منجر به كـاهش فرسـايش خــاك مسىشـود. ناديـهـ و همكاران (YV) در مطالعهاى تحت باران شبيهسازى بيان كردند كه ضريب رواناب به صورت قابل ملاحظهاى در شخم مـوازى شيب بيشتر از خاكورزى روى خطوط تراز بـر شـيب اسـت و همجنين شخم در جهت شيب بهصورت معنىدارى باعث كاهش ظرفيت ذخيره آب سطحى خـاك مسى شـود ( شـكل ه). بررسى مقادير بارندگى طى دوره رشد كندم ديم نشان داد كه بارندگى هــا اغلب در ماههاى آبان (99 ميلى متر)، آذر (9 ميلى متــر)، اسـفند 


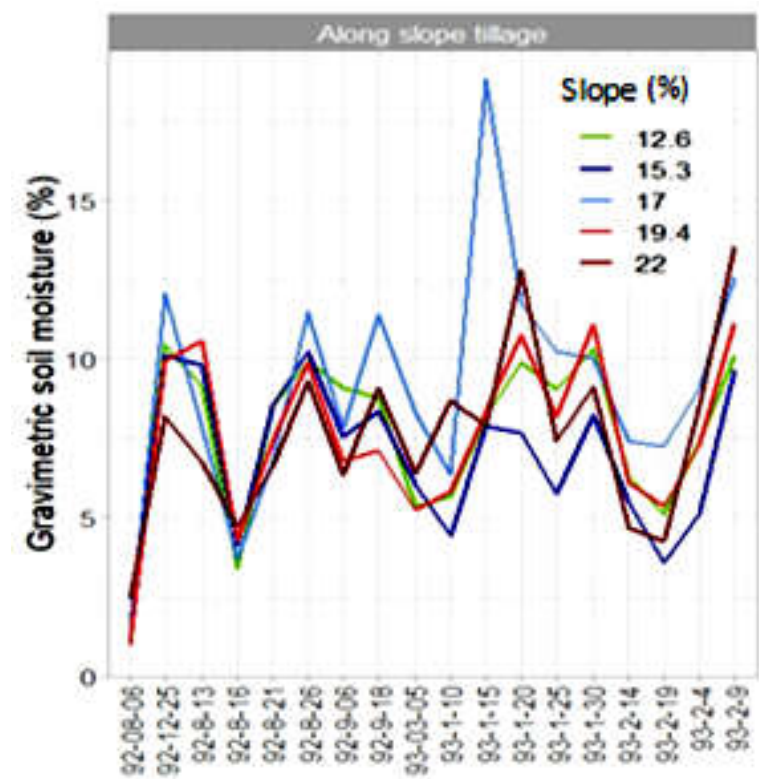

Date

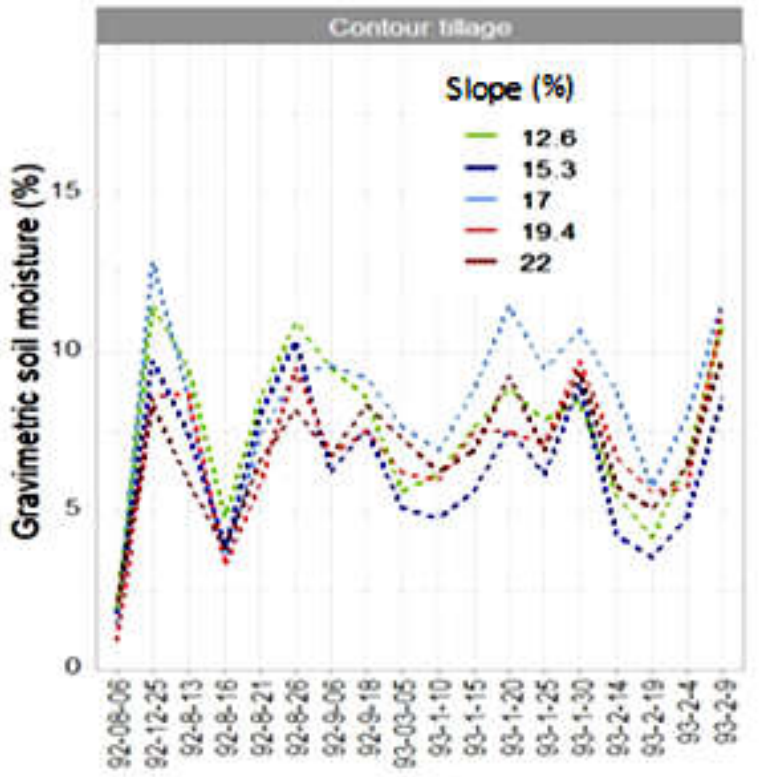

Date

(ب)

(الف)

شكل צ. تغييرات رطوبت جرمى خاك در دو جهت خاكورزى: الف) موازى شيب و ب) روى خطوط تراز در دامنهاى مورد بررسى

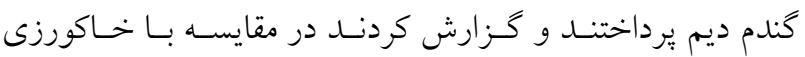
مرسوم، ساير عملياتهاى خاكورزى حفاظتى باعث بهبود ذخيـره

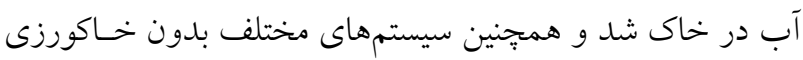
در مقايسه با خاكورزى مرسوم باعث بهبود عملكرد دانه شد. آنها

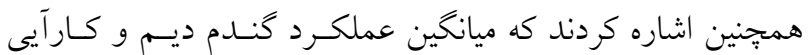
بهرهمندى از آب باران در خاكورزى روى خطوط تراز نسـبت بـهـ

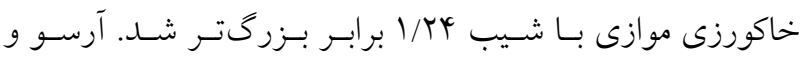

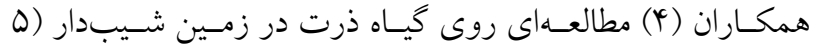
درصـــ در اتيـويى نشـان دادنـــ خـاكورزى همــراه بــا رويكـرد نكهدارى آب در خاك باعـث افـزايش مب درصـدى عملكـرد در سال اول و افزايش ه广 درصدى در سال دوم شد.
تفاوت بسيار آشكارى با خاكورزى موازى شيب نداشته باشد.

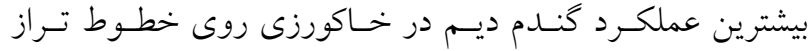

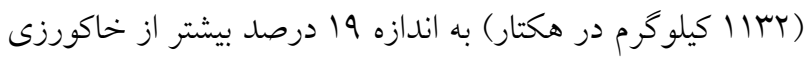
موازى شيب بود، همجنين بيشترين كار آيى بهرهمندى از آب بار باران نيز در خاكورزى روى خطوط تراز (آ/T كيلو كرم بر مترمكعبب) به اندازه 19 درصد بيشتر از خاكورزى موازى شيب بهدست آمـد. بهطور كلى ميانگين عملكرد دانه گُندم در خاكورزى روى خطوط

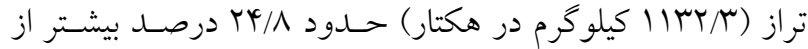
خاكورزى موازى شيب (909/9 كيلو گرم در هكتار ) بود. هانـخ و

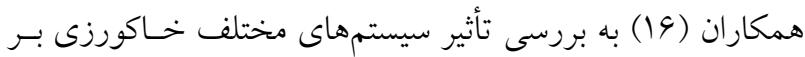

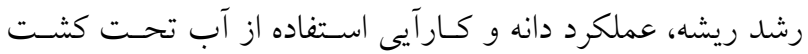




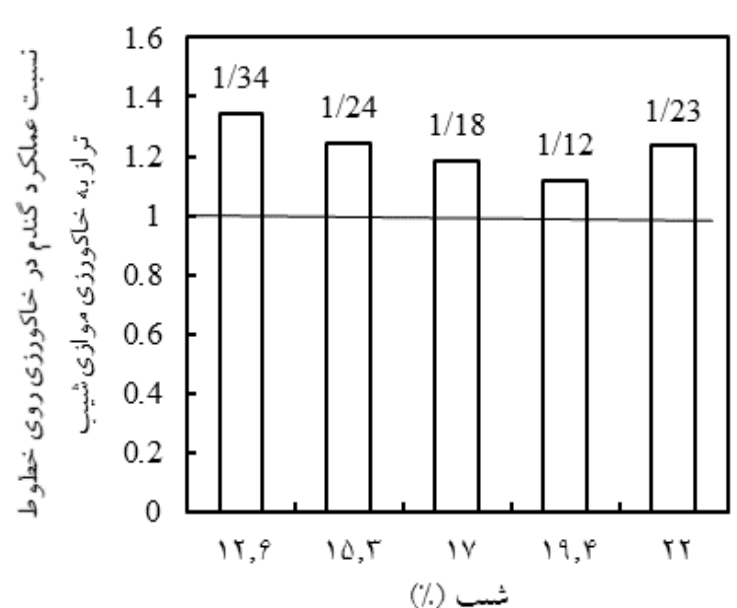

(ب)

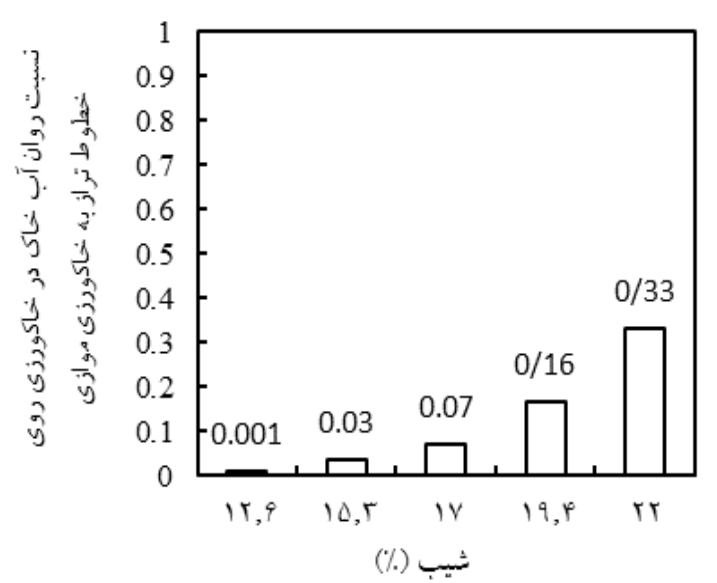

(د)

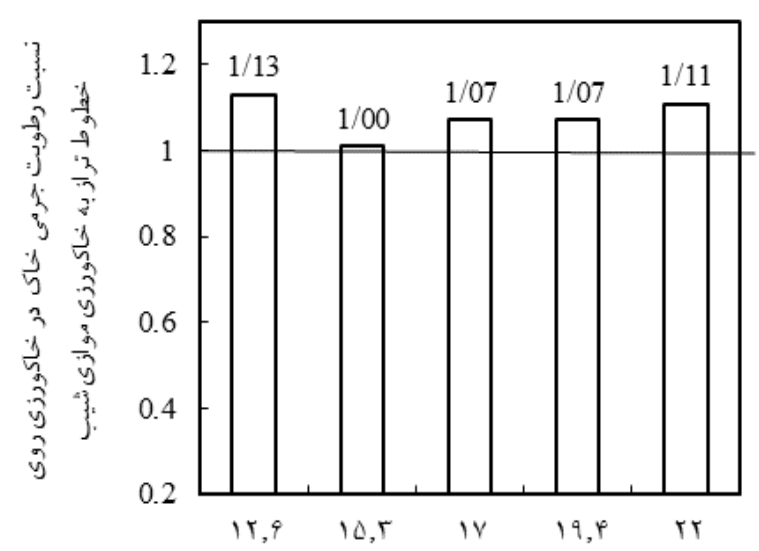

شيب (\%)

(الف)

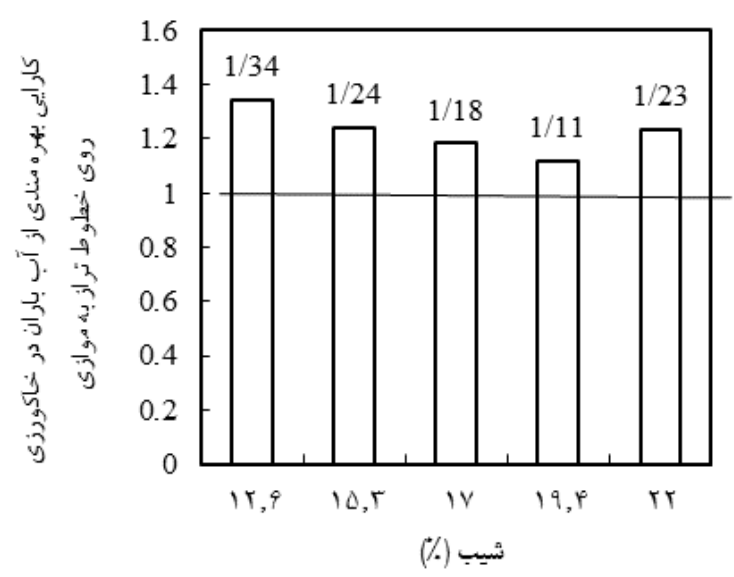

(ج)

شكل V. تغييرات: الف) رطوبت جرمى خاك، ب) عملكرد كندم ديم، ج) كارآيى بهرهمندى از آب كندم و د) رواناب در دامنههاى مورد (د

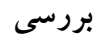

كاركرد ضعيف نوارهـاى كشـت در حفـظ بارنـدكى از كـارآيى

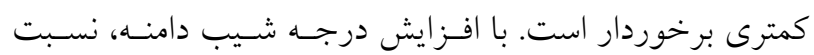

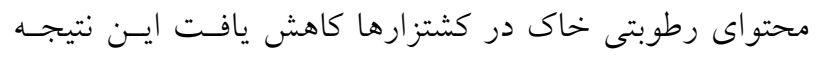

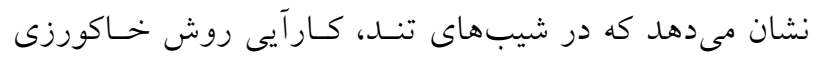
روى خطوط تراز در ذخيره آب باران كاهش بيدا مى كند. دليل

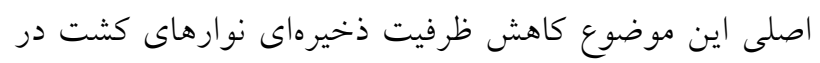

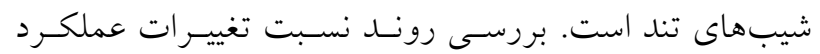

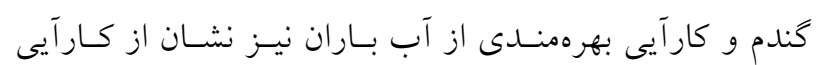

تغييرات عملكرد گندم و كار آيى بهرهمنسدى از آب بـاران و رواناب تحت تأثير شيب دامنه

شكل V تغييرات نسبت رواناب، رطوبت خاك، عملكرد گندم و

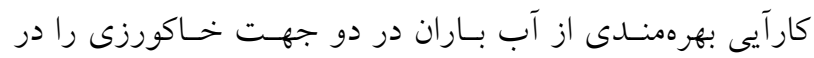

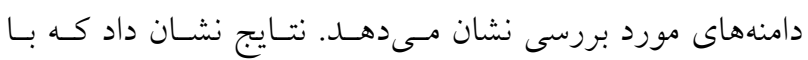
افزايش شيب دامنه، نسـبت توليـد روانـاب در خـاكورزى روى ترى

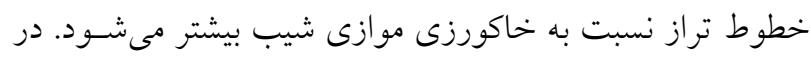
واقع در شيبهاى تند، خـاكورزى روى خطـوط تـراز بـهدليـل 
هر دو عامل درجه شيب و جهت خاكورزى قـرار دارنـد. توليـــ

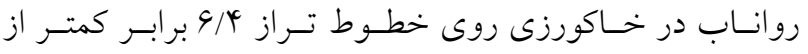
خاكورزى موازى شيب بود و اين موجــب شـــ مفــار رطوبـت خاك در ايسن جهـت خـاكورزى تـا N/N درصــ افـزايش يابــا.

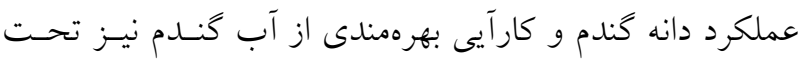

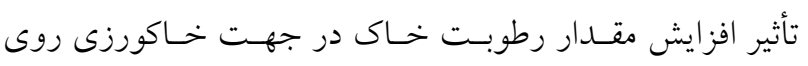
خطوط تراز قرار كرفتند. بهطورى كه در اين جهـت خـاكورزى

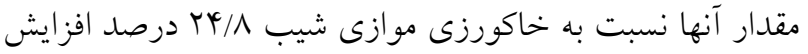

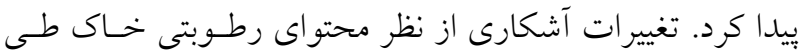
دوره رشد بهويزه در خاكورزى موازى با شـيب وجـود داشـت. شدت اين تغييرات در شيبهــاى تنـــــــارزتر بــود. بـا افـزايش درجه شيب بهدليل كاهش ظرفيت ذخيره آب، توليد روانـاب در خاكورزى روى خطوط تراز نسبت به خاكورزى مـوازى شـيب افزايش يافت و موجـب شـــ رطوبـت خـاك، عملكـــد دانسه و بهرهمندى از آب باران كاهش يابد. اين نتيجه نشاندهنده كاهش كارآيى روش خاكورزى روى خطوط تراز در حفظ آب و باران

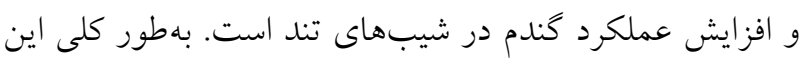

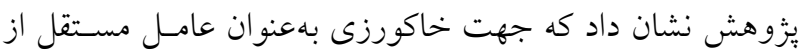
درجه شيب نقش مهمى در حفظ آب باران و افز ايش عملكـرد

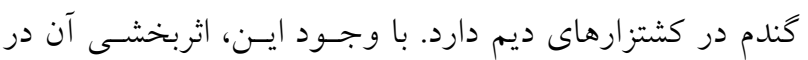

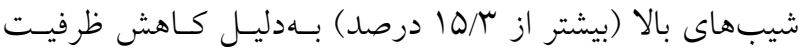

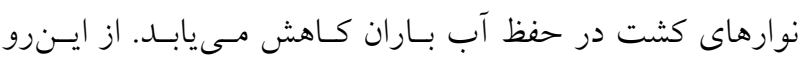

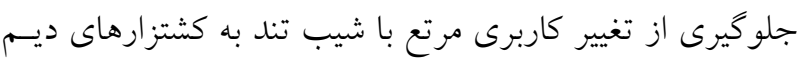

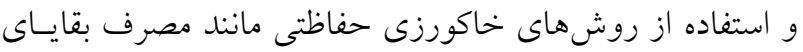
كياهى در كشتزارهاى با شيب تنــ از راهكارهـاى مــيريتى در كشتزارهاى ديم مناطق نيمه خشك مى تواند درنظر كرفته شوند.
كمتر روش خاكورزى روى خطوط تراز در افـزايش عملكـرد دانه كُندم و بهرهمندى از آب باران اسـت. در كشـتزارهاى بـا

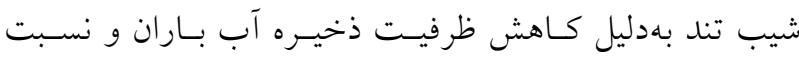
محتواى رطوبت خاك طى دوره رشد بين دو جهت خاكورزى

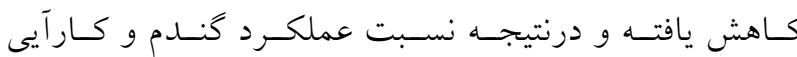
بهرهمندى از آب باران كاهش يافت. اقبال و همكـاران (1N) بـا

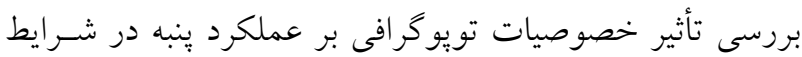

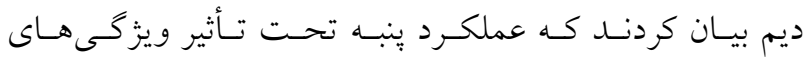

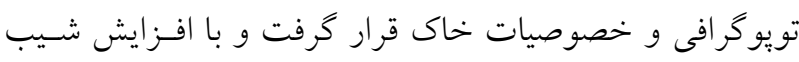
بهملت كاهش آب در دسترس كياه، عملكـرد كـاهش مسيابــ. آديماسو و همكاران (1) در مطالعهاى در اتيـويى عنسوان كردنـــ با افزايش شيب بهعلـت افـزايش روانـاب و هـــررفت خـاك و

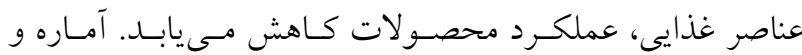

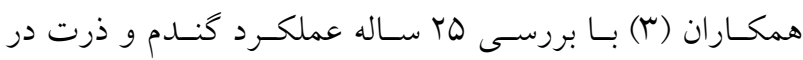
كشتزارهايى با شيبـهاى مختلـف نتيجـه كرفتنـــ كـه بيشـترين عملكرد محصول در ناحيههاى با كمترين شيب بهدست مى آيـد. جليليان (19) نيز بهمنظور تعيين اثر شيب بـر عملكـرد و برخى

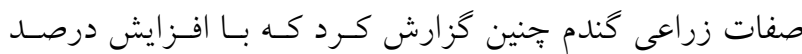

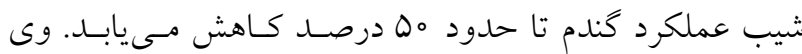
علت اين موضوع را تغييرات ميكرو كليما و ويزگى هـاى فيزيـك و شيميايى خاك در شيبهاى مختلف بيان كرد.

\section{نتيجه گيرى}

اين بزوهش نشان داد كه محتواى رطوبت خاك، عملكـرد دانسه كندم، كارآيى بهرهمندى از آب باران و توليد رواناب تحت تأثير

\section{منابع مورد استفاده}

1. Adimassu, Z., S. Langan, R. Johnston, W. Mekuria and T. Amede. 2017. Impacts of soil and water conservation practices on crop yield, run-off, soil loss and nutrient loss in Ethiopia: review and synthesis. Journal of Environmental Management 59: 87-101.

2. Ahmadi, A., V. Jafari, H. Paizwan Zand and M. A. Sadeq Zadeh. 2017. Changes in runoff and sediment production during growing season of rainfed chickpea (Case study: Ticme Dash, East Azarbaijan, Soil Conservation Research Station). Iranian Journal of Soil and Water Research 48(2): 299-308. (In Farsi). 
3. Amare, T., A. G. Terefe, Y. Selassie, B. Yitaferu, B. Wolfgramm and H. Hurni. 2013. Soil properties and crop yields along the terraces and toposequece of Anjeni Watershed, central highlands of Ethiopia. Journal of Agriculture Science 5: 134-144.

4. Araso, E., G. Tadele, A. Gemechu, M. Desalegn and D. Alemayhu. 2016. Effects of level Fanya Juu and Fanya Chin structures on grain yield of maize in moisture stress areas of daro labu District, West hararghe zone, Ethiopia. Journal of Biology Agriculture Healthcare 6: 94-98.

5. Bagheri, M. and A. R. Vaezi . 2018. Wheat grain yield and soil water content as affected by row spacing and plough directions in a dry-farming land. Journal of Water and Soil Conservation 24(5): 211-226. (in Farsi).

6. Boix-Fayos, C., A. Calvo-Cases, A. C. Imeson and M. D. Soriano-Soto. 2001. Influence of soil properties on the aggregation of some Mediterranean soils and the use of aggregate size and stability as land degradation indicators. Catena 44(1): 47-67.

7. Boujila, A. and T. Gallai. 2008. Soil organic carbon fraction and aggregate stability in carbonated and noncarbonated soils in Tunisia. Journal of Agronomy 7: 127-137.

8. Brouwer, C. and M. Heibloem. 1986. Management: Irrigation Water Needs Irrigation Water Management, Training Manuals 3. FAO.

9. De Vita, P., E. Di Paolo, G. Fecondo, N. Di Fonzo and M. Pisante. 2007. Notillage and conventional tillage effects on durum wheat yield, grain quality and soil moisture content in southern Italy. Soil and Tillage Research 92: 69-78.

10. Derpsch, R., A. J. Franzluebbers, S. W. Duiker, D. C. Reicosky, K. Koeller, T. Friedrich, W. G. Sturny, J. C. M. Sa and K. Weiss. 2014. Why do we need to standardize no-tillage research. Soil and Tillage Research 137: 16-22.

11. Diacono, M., A. Castrignanò, A. Troccoli, D. De Benedetto, B. Basso and P. Rubino. 2012. Spatial and temporal variability of wheat grain yield and quality in a mediterranean environment: A multivariate geostatistical approach. Field Crops Research 131: 49-62.

12. Emam, Y. 2011. Cereal Production. Shiraz University Press. Fourth Edition. (In Farsi).

13. FAO. 2018. FAO Statistical Year Book 2018, World Food and Agriculture. Food and Agriculture Organization of the United Nation, Rome, Available online at: http://www. fao.org/

14. Gee, G. W. and J. W. Bauder. 1986. Particle size analysis. PP. 383-411. In: Klute, (Eds.) Methods of Soil Analysis. Part $1,2^{\text {nd }}$ ed. America Society of Agronomy, Madison, WI.

15. Hodiani Mehr, A., M. Dahmardeh, I. Khammari and M. R. Asgharipoor. 2017. Effects of tillage systems on changes of soil nutrients, yield and land equivalent ratio in roselle - green gram intercropping. Iranian Journal of Field Crops Research 15(2): 311-322. (in Farsi).

16. Huang, G. B., Q. Chai, F. X. Feng and A. Z. Yu. 2012. Effects of different tillage systems on soil properties, root growth, grain yield, and water use efficiency of winter wheat (Triticum aestivum L.) in Arid Northwest China. Journal of Integrative Agriculture 11(8): 1286-1296.

17. Huang, Y. L., L. D. Chen, B. J. Fu, Z. L. Huang and J. Gong. 2005. The wheat yields and water-use efficiency in the Loess Plateau: straw mulch and irrigation effects. Journal of Agricultural Water Management 72: $209-222$.

18. Iqbal, M., A. Ali and M. Rizwanullah. 2005. Residual effect of tillage and farm manure on some soil physicalproperties and growth of wheat (Triticum aestivum L.). International Journal of Agriculture and Biology 7: 78-84.

19. Jalilian, J. 2015. The contribution of farm slopes and the use of different fertilizer sources in the formation of wheat yield. Journal of Crop Improvement 16(4): 819-828. (in Farsi).

20. Jin, H., L. Hongwena, G. A. Rabi, B. Rasaily, W. Qingjiea, C. Guohuaa, S. Yanboa, Q. Xiaodonga and L. Lnijic. 2011. Soil properties and crop yields after 11 years of no tillage farming in wheat-maize cropping system in North China Plain. Soil and Tillage Research 113: 48-54.

21. Jones, J. B. 2001. Laboratory Guide for Conducting Soil Tests and Plant Analysis. CRC Press, Boca Raton, FL.

22. Kebede, K. and E. Bekelle. 2008. Tillage effect on soil moisture storage and wheat yield on the vertisols of north central highlands of Ethiopia. Ethiopian Journal of Environmental Studies and Management 1(2): 49-55.

23. Kemper, W. D and R. C. Rosenau. 1986. Aggregate stability and size distribution models. Geoderma 123: 363-371.

24. Khurshid, K., M. Iqbal, M. S. Arif and A. Nawaz. 2006. Effect of tillage and mulchonsoil physical properties andgrowth ofmaize. International Journal of Agriculture and Biology 5: 593-596.

25. Komeili, H. R., P. R. Moghaddam, M. Ghodsi, M. Nassiri Mahallati and M. R. Jalal Kamali. 2016. Effect of different tillage methods and the rate of crop residues on yield, yield components and economic efficiency of wheat. Cereal Research 6(3): 323-337. (in Farsi).

26. Lean, E. O. 1982. Soil pH and lime requirement. PP: 199-224. In: A. L. Page (Eds.), Methods of Soil Analysis Chemical and Microbiological Properties. Part 2, 2nd ed., Agron. Monogr. No.9. ASA and SSSA, Madison.

27. Ndiaye, B., M. Esteves, J. P. Vandervaere, J. M. Lapetite and M. Vauclin. 2005. Effect of rainfall and tillage direction on the evolution of surface crusts, soil hydraulic properties and runoff generation for a sandy loam soil. Journal of Hydrology 307(1): 294-311. 
28. Nevo, E. 2002. Evolution of Wild Emmer and Wheat Improvement: Population Genetics, Genetic Resources, and Genome Organization of Wheat's Progenitor, Triticum dicoccoides. Springer.

29. Page, M. C., D. L. Sparks, M. R. Noll and G. J. Hendricks. 1987. Kinetics and mechanisms of potassium release from sandy middle Atlantic Coastal plain soils. Soil Science Society America Journal 51: 1460-1465.

30. Parihar, C. M., S. L. Jat, A. K. Singh, Y. Sing, S. Pradhan, V. Pooniya, A. Dhauja, V. Chaudhary, M. L. Jat, R. K. Jat and O. P. Yadav. 2016. Conservation agriculture in irrigated intensive maize-based systems of north-western India: Effects on crop yields, water productivity and economic profitability. Field Crops Research 193: 104-116.

31. Sadras, V. O. 2003. Influence of size of rainfall events on water-driven processes. I. Water budget of wheat crops in south-eastern Australia. Crop and Pasture Science 54(4): 341-351.

32. Shams Abadi, H. A. and S. Rafiee. 2007. Study on the effect of tillage practices and different seed densities on yield of rainfed wheat. Journal of Agricultural Science and Natural Resource 13: 95-102.

33. Shrefee, Z., S. V. Eslami, M. Jami AL-Ahmadi and S. Mahmoodi. 2018. Effect of different tillage methods and cover crop types on yield and yield components of wheat. Iranian Journal of Field Crops Research 16(1): $217-228$. (in Farsi).

34. Tan, Z. and R. Lal. 2005. Carbon sequestration potential estimates with changes in land use and tillage practice in Ohio, USA. Journal of Agriculture Ecosystems and Environment 111(1): 140-152.

35. Vaezi, A. R. and M. Piri. 2017. Water retention and wheat grain yield as affected by plough direction in a semi-arid rainfed land in west of Zanjan. Journal of Water and Soil Conservation 23(6): 285-299. (in Farsi).

36. Vaezi, A. R., H. A. Bahrami, H. R. Sadeghi and M. H. Mahdian. 2008. Modeling the USLE K-factor for calcareous soils in northwestern Iran. Geomorphology 97 (3-4): 414-423.

37. Van den Putte, A., G. Govers, A. Leys, C. Langhans, W. Clymans and J. Diels. 2013. Estimating the parameters of the Green-Ampt infiltration equation from rainfall simulation data: Why simpler is better. Journal of Hydrology 476: 332-344.

38. Wahbi, A. and T. R. Sinclair. 2005. Simulation analysis of relative yield advantage of barley and wheat in an eastern Mediterranean climate. Field Crops Research 91(2): 287-296.

39. Walkley, A and I. A. Black. 1934. Estimation of soil organic carbon by the chromic acid titration method. Soil Science 37: 29-38.

40. Western, A. W., R. B. Grayson, G. Bloschl, G. R. Willgoose and T. A. Mcmahon. 1999. Observed spatial organization of soil moisture and its relation to terrain indices. Journal of Water Resource Research 35(3): 797-810. 


\title{
Rain Water Use Efficiency of Rainfed Wheat (Triticum aestivum L.) as Affected by Tillage Direction in Slope
}

\author{
A. Vaezi ${ }^{*}$ E. Zarrinabadi and Y. Salehi ${ }^{1}$
}

(Received: December 1-2019; Accepted: February 27-2021)

\begin{abstract}
The effective use of rainwater is a key issue in agricultural development in arid and semi-arid regions. The tillage system as an important soil management measure can affect the rainwater retention, soil moisture content, and in consequence crop yield in rainfed lands. This study was conducted to evaluate the effects of slope gradient and tillage direction on rainwater use efficiency (RWUE) in rainfed lands in Zanjan Province. The field experiment was performed in five slope gradients $(12.6,15.3,17,19.4$, and 22\%) and two tillage directions (along slope and on contour tillage) at two replications. Mass soil water content was determined at 5-day intervals and runoff was measured after rainfalls. Wheat grain yield was determined for each plot and RWUE was computed using the proportion of wheat grain yield and precipitation. Base on the results, runoff, soil moisture, wheat grain yield, and RWUE were affected by tillage directions, so that runoff in contour line tillage decreased about 6.4 times compared to along slope tillage and in consequence increased soil moisture, wheat grain yield, and RWUE about 8.7, 24.8, and 24.8\%, respectively. Increasing runoff production in contour line tillage at steeper slopes was associated with a lower capacity of cultivated furrows that strongly declined soil water retention and negatively affected wheat grain yield and RWUE in the lands. This study revealed that the efficiency of the contour tillage in water retention and RWUE decreases in steeper slopes in rainfed lands.
\end{abstract}

Keywords: Precipitation, Conservation tillage, Runoff, Wheat yield, Soil moisture content

1. Soil Science Department, Faculty of Agriculture, University of Zanjan, Iran.

Corresponding author, Email: vaezi.alireza@gmail.com 